\title{
Pharmacogenetics for T2DM and Anti-Diabetic Drugs
}

\author{
Qiong Huang ${ }^{1}$ and Zhao-qian Liu ${ }^{2}$ \\ ${ }^{1}$ Institute of Clinical Pharmacology, Anhui Medical University, Key Laboratory of Anti- \\ inflammatory and Immunopharmacology of Education Ministry, Hefei, Anhui \\ 2Institute of Clinical Pharmacology, Hunan Key Laboratory of Pharmacogenetics, Central \\ South University, Changsha, Hunan \\ 1,2P. R. China
}

\section{Introduction}

\subsection{Genes associated with T2DM}

\subsubsection{Genes associated with ion transport}

\subsubsection{KCNJ11}

The potassium inwardly rectifying channel subfamily J member 11 (KCNJ11) gene encodes Kir6.2 protein, the inwardly rectifying potassium channel, which is a complex of two subunits [2]. ATP-sensitive $\mathrm{K}^{+}\left(\mathrm{K}_{\mathrm{ATP}}\right)$ channels critically control insulin secretion by coupling metabolism to electrical activity [3]. The $\beta$-cell channels are assembled, with tetradimeric stoichiometry, from two structurally distinct subunits: inwardly rectifying K-channel subunit (KIR6.2) and the regulatory sulfonylurea receptor subunit-1 (SUR1). Some studies showed that the KCNJ11 E23K (Lys23Glu, 67 G>A, rs5219) polymorphism could affect insulin secretion and T2DM susceptibility by influencing the sensitivity of the $\mathrm{K}_{\mathrm{ATP}}$ channel to ATP [4-6]. E23K promotes development of T2DM by increasing the threshold ATP concentration, thus inducing over activity of pancreatic $\beta$-cell $\mathrm{K}_{\mathrm{ATP}}$ channels and inhibiting insulin secretion [7]. E23K markedly affected channel gating, significantly reduced the time spent in long inter burst closed states. Meta-analysis of all case-control data showed that the E23K allele was associated with T2DM [8]. The E23K variant was associated with a reduction in estimates of glucose-induced serum insulin levels in middle-aged glucosetolerant subjects. This result is in accordance with the recent in vitro finding that the E23K variant is associated with a reduced ATP sensitivity of the Kir6.2/SUR1channel complex [4, 7]. T2DM patients with one A allele of the KCNJ11 E23K polymorphism seem to be more sensitive to repaglinide as compared with individuals with the GG genotype [9].

\subsubsection{KCNQ1}

KCNQ1 (potassium voltage-gated channel, KQT-like subfamily, member 1) gene, locates on $11 \mathrm{p} 15.5$, encodes a voltage-gated $\mathrm{K}^{+}$channel with six transmembrane regions and is expressed in the heart, stomach, small and large intestine, kidney and pancreas [10]. Two independent GWA studies identified that SNPs rs2237892, rs2237895, and rs2237897 located in intron 15 of the KCNQ1 gene were strongly associated with T2DM [6,7]. The association 
of rs2237892, rs2237897, and rs2283228 with T2DM was confirmed in populations of Korean, Singaporean, Chinese, European ancestry and Japanese. The risk allele of rs2237892, rs2237895, and rs2237897 were associated with impairment of insulin secretion according to the homeostasis model assessment of $\beta$-cell function or the corrected insulin response [11, 12]. In a Chinese study, SNP rs2237892 was significantly associated with increasing fasting plasma glucose, while rs2237892 and rs2237897 were associated with HbA1c. The SNP rs2237897 was associated with both acute insulin and C-peptide response after arginine stimulation in T2DM group. The SNP rs2237895 was associated with both first- and secondphase insulin secretions in the controls. For rs2237892, rs2237895 and rs2237897 polymorphisms, homozygous carriers of the diabetes-associated allele had significantly decreased BMI (body mass index) and waist circumferences [13]. In German population, the rs2237892, rs2237895 and rs2237897 were nominally associated with OGTT (oral glucose tolerance test)-derived insulin secretion indexes [14]. It has been reported that SNP rs2237892 affected repaglinide and rosiglitazone therapeutic response. Individuals who were rs2237892 TT homozygote carriers treated with repaglinide for 48 weeks exhibited lower 2-h glucose levels and significantly higher cumulative attainment rates of target 2-h glucose levels than the C allele carriers; patients with a greater number of rs2237892 C alleles showed larger augmentations in both fasting insulin and HOMA-IR. The rs2237895 C allele was also associated with greater increments in both fasting insulin and HOMA-IR. SNP rs2237897 associated with decrease in 2-h glucose levels in the rosiglitazone 48-week therapy [15]. The minor C-allele of rs2237895 of KCNQ1 gene, which had a prevalence of about $42 \%$ among Caucasians was associated with reduced measures of insulin release following an oral glucose load suggesting that the increased risk T2DM [16]. Another SNP rs151290 was associated with 30-min C-peptide levels during OGTT, first-phase insulin secretion, and insulinogenic index after adjustment in the dominant model in the population of mainland China [17]. And rs151290 was associated with glucose-stimulated gastric inhibitory polypeptide and GLP-1 increase after adjustment in the dominant model [14]. The molecular mechanism of KCNQ1 SNPs in the intron affects insulin secretion is unclear $[6,8,9]$, suggesting the important role of KCNQ1 in insulin secretion by pancreatic $\beta$-cells. The increased risk for T2DM associated with KCNQ1 is likely to be caused by a reduction in insulin secretion. Further studies will be needed to verify these findings and to fully delineate the role of KCNQ1 and its related pathways in disease pathogenesis [18] .

\subsubsection{SLC30A8}

GWA studies also identified that the zinc transporter solute carrier family 30 member 8 gene (SLC30A8) polymorphism was a risk of T2DM in several populations [19-25]. The SLC30A8 gene is an especially interesting candidate gene because of its exclusive expression in the pancreas and major in $\beta$-cell $[25,26]$. SLC30A8 gene encodes ion channel zinc transporter protein member $8(\mathrm{ZnT}-8)$, which is thought to be the $\beta$-cell zinc concentration regulator. ZnT-8 is a critical molecule during the insulin maturation and release process that carries zinc from the cytoplasm into insulin secretory vesicles [26]. Therefore, its polymorphisms may affect its activity, which in turns correlates with T2DM susceptibility and therapeutic efficacy. SNP rs13266634 polymorphism (973C >T) in SLC30A8 gene is a non synonymous SNP that causes an amino acid change from arginine (R) to tryptophan (W) at position 325 (Arg325Trp). This SNP is associated with T2DM onset and development in several populations [19-25]. It has been reported that the genetic polymorphism of SLC30A8 was associated with impaired proinsulin conversion involved in the production and secretion 
pathway [27]. Fu et al. found that reduced ZnT-8 expression in cultured pancreatic $\beta$ cells gives rise to reduced insulin response to hyperglycemia and that SLC30A8 polymorphism could affect insulin secretion and glycemic response [28]. Another two studies indicated that patients with the rs13266634 $\mathrm{C}$ allele showed decreased first-phase insulin release following an intravenously administered glucose load [29,30]. Furthermore, it has been found that the C alleles of rs13266634 at SLC30A8 were associated with increased FPG and decreased insulin during the OGTT. An investigation also showed SNP rs13266634 increased the risk for T2DM by 1.24-fold in Chinese Han population [30]. A Chinese population study explored SLC30A8 is one susceptibility gene for T2DM and influences response to repaglinide. T2DM patients with $\mathrm{T}$ allele showed a better repaglinide response on FINS and PINS compared with CC wild-type homozygote [31].

\subsubsection{WSF1}

Wolfram syndrome 1 (WFS1) gene encodes wolframin, a $100 \mathrm{kDa}$ transmembrane glycoprotein that maintains calcium homeostasis of the endoplasmic reticulum, which is expressed in neurons and pancreatic $\beta$-cells and regulates calcium fluxes in the endoplasmic reticulum [32]. WFS1 is critical for survival and function of insulin-producing pancreatic $\beta$ cells [33]. WFS1 gene polymorphism rs10010131 was confirmed with T2DM in several GWA studies [19-25]. In the Diabetes Prevention Program, it is noted a trend towards increased insulin secretion in carriers of the protective rs10010131 variants [34]. Rare mutations in WFS1 cause Wolfram syndrome, variation in WFS1 also predisposes to common T2DM. It has been reported that WFS1 gene variants were associated with reduced insulin response to oral but not intravenous glucose [35-39]. WFS1 gene was associated with estimates of a decreased pancreatic $\beta$-cell function among middle-aged individuals with abnormal glucose regulation [37]. WFS1 gene was also associated with impaired incretin signaling, the level of glycemia determines SNP effects on insulin secretion. This indicated the increasing relevance of these SNPs during the progression of prediabetes stages toward clinically overt T2DM [40].

\subsubsection{Genes involved in cell cycles}

\subsubsection{CDKAL1}

A variant in the cyclin-dependent kinase 5 (CDK5) regulatory subunit associated protein 1-like 1 (CDKAL1) gene was associated with T2DM in individuals of European ancestry and individuals from Hong Kong of Han Chinese ancestry [22]. SNP rs7756992 is located in intron 5 of the CDKAL1. It resides in a large LD block of $201.7 \mathrm{~kb}$ that includes the CDKAL1 gene exons 1-5 and the minimal promoter region but no other known genes. It has been proposed that polymorphism rs7756992 confers risk of T2DM through reduced insulin secretion because the insulin response for heterozygote was approximately $20 \%$ lower than for heterozygote or non carriers. The function of the CDKAL1 gene product is still unknown. But the CDKAL1 gene product is similar to CDK5 regulatory subunitassociated protein 1 (CDK5RAP1) gene product. CDK5RAP1 is expressed in neuronal tissues and inhibits CDK5 activity by binding to the CDK5 regulatory subunit p35. In pancreatic $\beta$-cells, CDK5 shows to act in the loss of $\beta$-cell function under glucotoxic conditions [41]. Inhibition of the CDK5/p35 complex prevents a decrease of insulin gene expression and glucotoxicity [42]. It is proposed that CDKAL1 may act in the inhibition of the CDK5/p35 complex in $\beta$-cells similar to CDK5RAP1 in neuronal tissue. Reduced 
CDKAL1 expression or inhibitory function could lead to an impaired response to glucotoxicity. The association of CDKAL1 rs7756992 with T2DM was replicated in Japanese [43], Chinese [30] and Indians populations [44]. And variants in CDKAL1 were strongly associated with $\beta$-cell function estimated by HOMA- $\beta$ (Homeostasis model assessment for $\beta$ cell function) [30]. Evidence from previous GWA studies implicating variants in $C D K A L 1$ and near $C D K N 2 A / B$ implies that cell cycle dysregulation may be a common pathogenetic mechanism in T2DM [19, 20, 24].

\subsubsection{CDKN2A/B}

Cyclin-dependent kinase inhibitor-2A/B (CDKN2A/B) gene encode p15INK4b and p16 INK4a protein which are tumor suppressors that inhibit cyclin-dependent kianse 6 (CDK6) and CDK4, respectively. CDKN2B and CDKN2A are expressed in pancreatic islets and adipocytes [19, 20, 24]. CDKN2A/2B (rs10811661) was associated with T2DM [45]. SNP rs10811661 located $125 \mathrm{~kb}$ upstream of the CDKN2B and CDKN2A genes, has been associated with T2DM in three of the GWA studies (OR for pooled studies 1.20 [95\% CI 1.14-1.25], $\left.P=5 \times 10^{-15}\right)[19,20,24]$. And the association was confirmed in Danish, Norwegian, French, Korean, Japanese and Chinese participants [10-15]. In murine models studies suggest that the rs10811661 polymorphism located upstream of the CDKN2B and CDKN2A genes may confer increased risk for T2DM by affecting $\beta$ cell function [46-48].

\subsubsection{CDC123/CAMK1D}

SNP rs12779790 is located $\sim 90 \mathrm{~kb}$ from cell division cycle 123 homolog [S. cerevisiae] (CDC123) gene and $63.5 \mathrm{~kb}$ from calcium/calmodulin-dependent protein kinase I delta (CAMK1D) gene. CDC123 gene encodes a protein involved in cell cycle regulation and nutritional control of gene transcription [23, 49]. CAMK1D regulates granulocyte function [50], it is also possible that a causative variant in this region is related to CAMK1D and affects pancreatic $\beta$-cell function through increased apoptosis. SNP rs12779790 is found associated with T2DM in several studies. G risk allele of rs12779790 was associated with a lower insulin genic index, corrected insulin response, and area under the insulin/glucose curve during OGTTs and a lower DI in carriers of the G allele [51]. In Asian Indian descent subjects also found the $\beta$-cell defect [34]. Trend toward lower $\beta$-cell function could be observed in Caucasians population [35, 38, 52]. SNP rs12779790 variation carriers showed a lower insulin response to glucose stimulation and noted a trend toward a reduced insulin response after arginine stimulation. Arginine stimulation during hyperglycemia is a measure of (near) maximal insulin secretion and has been suggested as a proxy for $\beta$-cell mass. This gene variant affected $\beta$-cell function by causing reduced $\beta$-cell mass due to enhanced apoptosis [50].

\subsubsection{Genes involved in gene transcription}

\subsubsection{TCF2}

The SNPs rs7501939 and rs4430796 on 17q12 are located in the first and second intron of the transcription factor 2 isoform $b$ (TCF2) gene, respectively [53]. One of the variants is in TCF2 $(H N F-1 \beta)$, a gene known to be mutated in individuals with maturity-onset diabetes of the young type 5 [54]. SNPs in TCF2 are also associated with both T2DM and prostate cancer $[53,54]$. Three genes with common variants that influence risk of T2DM were first discovered based on rare Mendelian mutations (KCNJ11, WSF1 and TCF2). This is 
particularly interesting given the recent finding that SNPs in TCF2 are also associated both with T2DM and prostate cancer [53, 54].

\subsubsection{TCF7L2}

Transcription factor 7-like 2 (TCF7L2) gene encodes a transcription factor (Tcf-4) which involved in the regulation of cellular proliferation and differentiation [55]. TCF7L2 plays an important role in the Wnt signaling pathway. TCF7L2 is involved in the growth, differentiation, proliferation, and insulin secretion of pancreatic $\beta$-cells [56]. GWA studies found variants in the TCF7L2 showed to be associated with an increased risk for T2DM [19, $20,22,23,25,57]$. The strongest associations with T2DM with a clear gene dose effect were reported for the rs7903146 variant [58]. TCF7L2 was found to be associated with less weight loss in response to lifestyle intervention [59]. Genetic variants in the exon 4 (including rs7903146) block of TCF7L2 were associated with impaired insulin secretion and incident diabetes in a prospective Chinese cohort [60]. TCF7L2 gene polymorphism also affected the drug response for T2DM therapy which was the only predictor of sulfonylureas treatment failure [61]. The rs7903146 T-allele conferred a higher risk for sulfonylurea treatment failure [61]. It has been observed that homozygous carriers of the TCF7L2 risk alleles (rs1225372 and rs7903146) were twice as likely not to respond to sulfonylureas as patients homozygous for the non-risk alleles [62].

\subsubsection{HHEX}

GWA studies identified that the haematopoietically expressed homeobox (HHEX) gene polymorphism was a risk of T2DM in several populations [19-25]. HHEX encodes the transcription factor hematopoietically expressed homeobox protein, which is expressed in the embryonic ventral-lateral foregut that causes the ventral pancreas and the liver [63]. It has been confirmed the significant association of HHEX with T2DM in the Japanese population [64]. HHEX was a common T2DM-susceptibility gene across different ethnic groups. The OR values of the three SNPs rs1111875, rs5015480 and rs7923837 genotyped in HHEX (1.20-1.46) were higher in Japanese than those of the European population (1.20) [64]. HHEX variant was associated with impaired proinsulin conversion [38]. SNP rs1111875 and rs7923837 was associated with T2DM independent of body fat [65]. SNP rs7923837 in the 3'flanking region of the HHEX locus was associated with altered glucose-stimulated insulin release. This SNP's major allele represented a risk allele for $\beta$-cell dysfunction and might confer increased susceptibility of $\beta$-cells toward adverse environmental factors [66]. Knockout of HHEX gene showed impair proliferation of endodermal epithelial cells, positioning of ventral foregut endoderm cells relative to the mesoderm, and budding and morphogenesis of the ventral pancreas [63]. This genetic manipulation finally provoked lethality during midge station [63].

\subsubsection{JAZF1}

The juxtaposed with another zinc finger gene 1 (JAZF1) gene encodes a transcriptional repressor of nuclear receptor subfamily 2, group C, member 2 (NR2C2) with three $\mathrm{C} 2 \mathrm{H} 2-$ type zinc fingers [67]. Mice deficient in Nr2c2 exhibit growth retardation, low IGF1 serum levels, and perinatal and early [53, 54] stnatal hypoglycaemia [68]. JAZF1 is expressed in pancreas, brain, thalamus, liver, uterus, endometrial and prostate. In a meta-analysis in East Asians, it has been found that the variant of JAZF1 rs864745 was significantly 
associated with T2DM [69]. SNP rs864745 is in intron 1 of the JAZF1 gene. The major Tallele of the rs 864745 conferring increased diabetes risk was associated with increased 2nd phase serum insulin release during an IVGTT, and an increased fasting serum insulin level [69]. Carriers of the diabetes-associated T-allele of rs 864745 had an allele dependent $3 \%$ decrease in BIGTT-AIR. JAZF1 is expressed in the pancreas [67], one might speculate that a gain-of-function variant in JAZF1 may lead to postnatal growth restriction also affecting pancreatic $\beta$-cell mass and function [51]. SNP rs864745 in JAZF1 were significantly associated with traits of insulin secretion in a glucose-tolerant Danish population [51].

\subsubsection{Others}

\subsubsection{PPAR- $\gamma 2$}

Peroxisome proliferator-activated receptor- $\gamma 2$ (PPAR- -2$)$ is one of PPAR- $\gamma$ isoforms and is a member of the nuclear hormone receptor subfamily of transcription factors, which regulates transcription of various genes [70]. $P P A R-\gamma$ plays an important role in adipocyte differentiation, regulating glucose, and lipid homeostasis [70]. Pro12Ala is one of important polymorphism in codon 12 of exon B causing proline-to-alanine change [71]. The Ala allele reduces the transcriptional activity of PPAR- $\gamma 2$ and may protect against T2DM compared with the more common Pro/Pro genotype $[72,73]$. The effects of the PPAR-y2 Pro12Ala polymorphism on glucose and insulin metabolism may be modified by prenatal exposure to famine during midge station [74]. Patients with the Pro12Ala genotype had a better therapeutic response to rosiglitazone than the Pro12Pro genotype subjects. The genetic variations in the PPAR- $\gamma 2$ gene can affect the response to rosiglitazone therapeutic efficacy in T2DM patients [75].

\subsubsection{IGF2BP2}

Insulin-like growth factor 2 mRNA-binding protein 2 (IGF2BP2) belongs to an mRNAbinding protein family that plays role in RNA localization, stability and translation [76]. IGF2BP2 is highly expressed in pancreatic islets and binds to insulin-like growth factor 2 (IGF-2), which is an important growth and insulin signaling molecule [24]. IGF2BP2 is a homolog of IGF2BP1, which binds to the 5'UTR of IGF2 mRNA and regulates IGF2 translation [77]. Several GWA studies have found that subjects carrying mutant alleles of SNPs rs1470579 and rs4402960 in IGF2BP2 gene showed a moderately increased risk of T2DM. Several studies have confirmed this result in Asian populations [30, 57, 78, 79]. T2DM patients with different IGF2BP2 genotypes showed various levels of insulin secretion. It has been demonstrated that variants in IGF2BP2 gene affect first-phase insulin secretion and the disposition index detected by hyperglycemic clamps [80].

Interactions between genetic variation in IGF2BP2 and T2DM maybe exerted through this IGF2 pathway and through the insulin pathway. The IGF2BP2 gene is located at chromosome 3q27.2. Intron 2 is the longest intron among mammalian species. SNPs rs1470579 and rs4402960 are located in a 50-kb region of this intron. Diabetes-predisposing variants may affect regulation of IGF2BP2 expression [20]. The IGF2BP2 gene variant (rs4402960) was associated with insulin sensitivity, FPG, glucose AUC, and FPG [81]. SNP rs4402960 was also associated with reductions in first-phase insulin secretion and in the disposition index, which reflected the failing adaptive capacity of pancreatic $\beta$-cells [80] resulting in hyperglycemia including FPG and PPG. SNP rs4402960 has also been shown to be associated with the 
disposition index in Hispanic Americans [82], HOMA- $\beta$ in non-diabetic Japanese individuals and lower acute insulin release and tolerance [64]. SNP rs4402960 is strongly associated with an increased risk of T2DM and increased AUC of glucose in individuals of Dutch descent [83]. Wu et al observed a significant association of SNPs (rs1470579 and rs4402960) in IGF2BP2 [1.17 (1.03-1.32); $P=0.014$ ] with combined IFG (impaired fasting glycemia)/T2DM group. The association of these SNPs with HOMA- $\beta$ reduction suggested that IGF2BP2 gene confers T2DM risk through a reduction of $\beta$-cell function [30]. Another study in Chinese T2DM population according with these results and found IGF2BP2 variations effect on the therapeutic efficacy of repaglinide treatment in Chinese T2DM patients. Patients with the rs1470579 AC+CC genotypes had poor responses to repaglinide treatment with respect to FPG and PPG compared with individuals with the AA genotype. Patients with the GT+TT genotypes of rs4402960 also showed a better repaglinide therapeutic effect on PINS compared with individuals with the GG genotype. Replication of this research has indicated that IGF2BP2 variants were more likely to be associated with reduced $\beta$-cell function [80, 84]. IGF2BP2 was shown to affect insulin secretion in a previous study. Understanding the biological mechanism by which variants in IGF2BP2 could mediate these effects on the biphasic pattern of insulin secretion will require further investigation.

\subsubsection{FTO}

Fat mass and obesity associated (FTO) gene was found in a GWA study for T2DM susceptibility genes identified and showed to predispose to diabetes through an effect on BMI [85]. SNPs rs9939609 in the FTO gene region on chromosome 16 was strongly associated with T2DM [85]. A number of SNPs in tight linkage disequilibrium with rs9939609, and residing in the first intron of the FTO gene, had been associated with obesity in large populations of adults and children. It had been showed that common variation rs9939609 was reproducibly associated with BMI and obesity from childhood into old age [86]. And recently it has been identified T2DM risk variants only the risk variant of the FTO gene (rs8050136) showed statistically significant association with BMI, FMI, and Waist Circumferences [87] .Some data indicated that FTO SNP rs9939609 was associated with differences in BMI, with the presence of the A allele linked to a greater risk of increased BMI and increased values for specific measures of adiposity, such as the sum of skin fold values and total body water as assessed by isotope analysis [88].

\subsubsection{THADA}

THADA (thyroid adenoma associated) gene encodes thyroid adenoma-associated protein may involve in the death receptor pathway and apoptosis [89]. Disruption of THADA by chromosomal rearrangements (including fusion with intronic sequence from PPAR- $\gamma$ ) is observed in thyroid adenomas [90]. The function of THADA has not been wellcharacterized, but there is some evidence to suggest that it may be involved in the death receptor pathway and apoptosis $[89,91]$. The THADA gene variant was also associated with lower $\beta$-cell response to GLP-1 and arginine, suggested lower $\beta$-cell mass as a possible pathogenic mechanism [92]. SNP rs7578597 was a non-synonymous SNP causing threonine to alanine in 1187 position which strongly associated with T2DM (combined OR [95\%CI] of 1.15[1.10-1.20], $P=1.1 \times 10^{-9}$ ) resided in exon 24 of THADA gene[23]. Subjects with the rs7578597 (T1187A) gene variant in THADA had a reduced $\beta$-cell mass due to increased apoptosis [92]. Analyses in the control subjects showed that THADA SNP rs7578597 was association with 2-h insulin during oral glucose tolerance tests [93]. 


\subsubsection{TSPAN8/ LGR5}

Tetraspanin 8 is a cell-surface glycoprotein, widely expressed cell surface glycoprotein known to form complexes with integrins to regulate cell motility in cancer cell lines [23, 94]. Tetraspanin 8 gene (TSPAN8) polymorphism rs7961581 was one of the strongest statistical signals associated with T2DM. SPAN8/LGR5 rs7961581 was significantly associated with T2DM in a meta-analysis in East Asians [69]. SNP rs7961581 associated with decreased levels of CIR, of AUC-insulin/AUC-glucose ratio, and of the insulinogenic index [51]. SNP rs7961581 resided $\sim 110 \mathrm{~kb}$ upstream of TSPAN8 gene. Because 6-integrin binding to laminin had been shown to negatively affect pancreatic $\beta$-cell mass maintenance [95], it was possible that variation in TSPAN8 influenced pancreatic $\beta$-cell function.

\subsubsection{ADAMTS9}

ADAMTS9 is a member of the ADAMTS (a disintegrin and metalloproteinase with thrombospondin motifs) protein family which has been implicated in the cleavage of proteoglycans [96], the control of organ maturation, development [97] and inhibition of angiogenesis [98]. ADAMTS9 is a secreted metalloprotease that cleaves the proteoglycans versican and aggrecan, and is expressed in skeletal muscle and pancreas [23]. SNP rs4607103 in ADAMTS9 gene representing a cluster of associated SNPs, resides $\sim 38 \mathrm{~kb}$ upstream of the ADAMTS9 gene, and also associated with T2DM susceptibility [52]. It has been found common diabetes-related C allele of rs4607103 at chromosome 3p14.3-2 upstream of ADAMTS9 was associated with a decrease in insulin sensitivity of peripheral tissues, as estimated from a euglycemichy perinsulinemic clamp [69]. And impairment of insulin sensitivity occurred in the presence of an increase in serum insulin levels in response to intravenous and oral glucose loads [69]. The major C-risk allele of rs4607103 near ADAMTS9 conferred increased risk of T2DM, associated with increased fasting plasma glucose levels and reduced insulin-stimulated glucose uptake during a euglycemic-hyperinsulinemic clamp. The C-risk allele also showed statistically significant associations with increased levels of serum insulin at $30 \mathrm{~min}$ after oral ingestion of glucose as well as with increased first and second phase serum insulin release as estimated from an IVGTT [99].

\subsubsection{NOTCH2}

Notch 2 (Notch homolog 2 [Drosophila]) expresses when pancreatic buds branch and is restricted to embryonic ducts, should be the source for endocrine and exocrine stem cells in mice $[23,100]$. Notch pathway plays key role in dictating endocrine differentiation. Activation of this pathway is critical for the maintenance of the progenitor pool between the first and second transitions of pancreatic development [101]. NOTCH2 is a type 1 transmembrane receptor. The SNP rs10923931 residing in intron 5 of the NOTCH2 gene strongly associate with T2DM susceptibility. SNP rs10923931 is near complete linkage disequilibrium with SNP rs2641348 in the ADAM30 gene [23]. Rs2641348, a non-synonymous SNP (L359P) within the neighboring ADAM metallo-peptidase domain 30 gene (ADAM30) represented the same signal $\left(r^{2}=0.92\right.$ based on HapMap CEU data) and was also followed-up.

\subsubsection{PTPRD}

A GWA study in Chinese population identified two genes, PTPRD and SRR, which were not previously described to be involved in diabetes or glucose metabolism [102]. PTPRD is the protein tyrosine phosphatase receptor type D gene and widely expressed in skeletal muscle, pancreas, and brain which belong to the receptor type IIA (R2A) subfamily of protein tyrosine phosphatases (PTPs). The R2A PTP subfamily comprises leukocyte common 
antigen-related (LAR), protein tyrosine phosphatase sigma (PTPRS), and PTPRD. The R2A family has been implicated in neural development, cancer, and diabetes [103]. PTPRDdeficient mice exhibited impaired learning and memory, early growth retardation, neonatal mortality, posture and motor defects [104]. LAR- and PTPRS-deficient mice showed defected glucose homeostasis and insulin sensitivity [105-107]. Transgenic mice over expressing LAR in skeletal muscle showed whole-body insulin resistance [108]. R2A subfamily members have similar structure [109]. PTPRD could act in T2DM pathogenesis and affect insulin signaling on its target cells. But it need further

\begin{tabular}{|c|c|c|c|c|c|}
\hline Gene & SNP & Position & Effect & References & Chromosome \\
\hline$\overline{\mathrm{KCNJ} 11}$ & rs5219 & Exon & E23K & [25] & 11p15.1 \\
\hline PPAR-ү2 & rs1801282 & Exon B & P12A & [74] & $3 p 25$ \\
\hline \multirow[t]{2}{*}{ TCF2 } & rs7501939 & Intron 1 & / & [53] & \multirow{2}{*}{$17 \mathrm{q} 12$} \\
\hline & rs4430796 & Intron 2 & / & [53] & \\
\hline \multirow[t]{4}{*}{ WSF1 } & rs10010131 & Intron & / & [40] & \multirow{4}{*}{$4 \mathrm{p} 12$} \\
\hline & rs752854 & Intron & / & [37] & \\
\hline & rs6446482 & Intron & / & [37] & \\
\hline & rs734312 & Exon & H61R & [37] & \\
\hline TCF7L2 & rs7903146 & Exon 4 & & [58] & $10 q 25.3$ \\
\hline \multirow[t]{3}{*}{ HHEX } & rs1111875 & 3'-UTR & / & [20] & \\
\hline & rs5015480 & $?$ & / & [20] & \\
\hline & rs7923837 & $?$ & / & [20] & \\
\hline SLC30A8 & rs13266634 & Exon 8 & R325W & [25] & $8 q 24.11$ \\
\hline \multirow[t]{4}{*}{ CDKAL1 } & rs7756992 & Intron 5 & / & [22] & \\
\hline & rs7754840 & $?$ & / & [118] & $6 \mathrm{p} 22.3$ \\
\hline & rs9465871 & $?$ & / & [30] & \\
\hline & rs10946398 & $?$ & / & [30] & \\
\hline CDKN2A-2B & rs10811661 & $?$ & / & [19] & $9 \mathrm{p} 21$ \\
\hline \multirow[t]{2}{*}{ IGF2BP2 } & rs1470579 & Intron 2 & / & [20] & $3 q 27.2$ \\
\hline & rs4402960 & Intron 2 & / & [20] & \\
\hline \multirow[t]{2}{*}{ FTO } & rs8050136 & Intron & / & [87] & $16 q 12.2$ \\
\hline & rs9939609 & Intron 1 & & [86] & \\
\hline JAZF1 & rs864745 & Intron 1 & / & [23] & 7p15.2-p15.1 \\
\hline CDC123/CAMK1D & rs12779790 & $?$ & / & [23] & $10 \mathrm{p} 13$ \\
\hline THADA & rs7578597 & Exon 24 & T1187A & [23] & $2 \mathrm{p} 21$ \\
\hline TSPAN8 & rs7961581 & $?$ & / & [23] & $12 \mathrm{q} 14.1-\mathrm{q} 21.1$ \\
\hline ADAMTS9 & rs4607103 & near & / & [23] & $3 p 14.3-2$ \\
\hline NOTCH2 & rs 10923931 & Intron 5 & / & [23] & 1p13-p11 \\
\hline PTPRD & rs17584499 & Intron 10 & / & [102] & 9p24.1-p23 \\
\hline \multirow[t]{2}{*}{ SRR } & rs391300 & & & [102] & $17 \mathrm{p} 13.3$ \\
\hline & rs4523957 & & & [102] & \\
\hline \multirow[t]{5}{*}{ KCNQ1 } & rs2237892 & Intron 15 & / & [23] & $11 \mathrm{p} 15.5$ \\
\hline & rs2237895 & Intron 15 & / & [23] & \\
\hline & rs2237897 & Intron 15 & / & [23] & \\
\hline & rs2283228 & Intron 15 & / & [11] & \\
\hline & rs151290 & Intron 15 & I & [17] & \\
\hline
\end{tabular}

Table 1.1 Summary of associated genes 
characterize. PTPRD gene polymorphism rs17584499 showed significant association with $\operatorname{T2DM}(P=8.54610-10$; odds ratio $[\mathrm{OR}]=1.57 ; 95 \%$ confidence interval $[\mathrm{CI}]=1.36-1.82)$ [102]. This SNP locates in intron 10.

\subsubsection{SRR}

SRR (serine racemase) gene encodes aserine racemase that synthesizes D-serine from Lserine $[110,111]$. D-serine (co-agonist) and the neurotransmitter glutamate bind to the Nmethyl Daspartate (NMDA) receptors and trigger excitatory neurotransmission in the brain $[102,112,113]$. NMDA receptor activation requires binding of glutamate and D-serine, which plays a neuromodulatory role in NMDA receptor transmission, synaptic plasticity, cell migration, and neurotoxicity [62]. D-serine and SRR express in the pancreas [114]. Glutamate signaling has function involved in positively regulates insulin and glucagon secretion in pancreatic islets [115-117]. Thus, SRR and D-serine may play roles in the etiology of T2DM. SNPs rs391300 and rs4523957 in the SRR gene were associated with T2DM in a Han Chinese GWA study. SNPs rs391300 and rs4523957 were in tight LD with each other $\left(\mathrm{r}^{2}=0.942\right.$ in HapMap HCB)[102]. The nearby SNP rs216193 also showed significant association; this SNP resides $3.8 \mathrm{~kb}$ upstream from SRR. SNP rs216193 was in tight LD with rs391300 ( $\mathrm{r}^{2}=0.942$ in HapMap HCB) [102].

\section{Anti-diabetic drugs pharmacogenetics}

\subsection{Insulin secretagogue agents ------sulfonylureas (SUs)}

The sulfonylurea anti-diabetic agents are insulin secretogogues including the first generation sulfonylureas (acetohexomide, chlorpropamide, tolazamide and tolbutamide) and second generation sulfonylureas (glibenclamide (glyburide), glipizide, gliclazide, and glimepiride) which are most widely used for T2DM treatment by closing the pancreatic $\beta$ cell potassium channels and stimulation insulin secretion [119].

\subsubsection{Cytochrome P450}

Sulfonylurea hypoglycemic agents are metabolized by cytochrome P450 2C9 (CYP2C9) enzyme. Genetic polymorphisms Arg144Cys (CYP2C9*2) and Ile359Leu (CYP2C9*3) could affect the safety and efficacy of sulphanylureas drugs in T2DM patients [120]. CYP2C9 genotypes significantly affected glyburide pharmacokinetics. Carriers with CYP2C9 variant *3 had decreased oral clearances [121]. Suzuki et al reported the subjects with CYP2C9*3 alleles showed the metabolic activity decrease of glimepiride hydroxylation and a marked elevation in the plasma concentrations of glimepiride, compared with subjects with a CYP2C ${ }^{*} 1 /{ }^{*} 1$ (wild type). The elevated glimepiride concentrations in subject with $C Y P 2 C 9^{*} 1 / * 3$ may increase the pharmacological effects [122]. Zhang et al reported the pharmacokinetics of gliclazide modified release were affected mainly by CYP2C19 genetic polymorphism in healthy Chinese subjects [123].

\subsubsection{Sulfonylurea receptor}

The sulphonylurea receptor is a subunit of the ATP-sensitive potassium channel located in pancreatic $\beta$-cell. The variants in the exon $16-3 C / T$ variant (rs1799854) of SUR1 (Sulfonylurea Receptor 1) was associated with T2DM and 25\% reduction in second-phase insulin secretion in -3T allele carriers in Dutch subjects with normal glucose tolerance (NGT) and impaired glucose tolerance (IGT) [124]. The association also found in Japanese [125] and 
Finnish population [126]. A recent publication reported genotyped 25 SNPs from 661 Chinese T2DM patients who received 8 weeks of gliclazide therapy. The subjects with GG genotype in SUR exon 33(S1369A, rs757110) had a 7.7\% greater decrease in FPG and $11.9 \%$ greater decrease in $\mathrm{HbA1c}$ after 8 weeks of gliclazide therapy [127].

\subsubsection{Others}

It was described that the exon 33 of the ABCC8 (rs757110) and KCNJ11 (rs5210) genes were associated with gliclazide antidiabetic efficacy [127]. SNPs of TCF7L2 had been consistently associated with T2DM in different ethnic descent and also had great impact on the T2DM patients' response to sulfonylureas [128]. The Go-DARTS2 study reported that the $\mathrm{T}$ allele of rs7903146 was associated with increased HbA1c in both cases and controls [129]. The same study group revealed that carriers of TCF7L2 variants were more likely to fail sulfonylurea therapy but not metformin (HbA1c $>7 \%$ ) within 3-12 months of treatment initiation [62].

Hepatocyte nuclear factor-1a (HNF-1a) is a homeodomain-containing transcription factor that expressed in the pancreatic $\beta$-cell and HNF-1a SNPs have been associated with $\beta$-cell dysfunction and maturity onset diabetes of the young (MODY) [130]. Variations in HNF-1a polymorphisms of T2DM were reported to be more sensitive to the hypoglycaemic effects of sulfonylureas [131-133]. Pearson et al reported that patients with HNF-1a polymorphisms (P129T, E132K, R159W, R229P, W267R and P291fsinsC) had a 5.2-fold greater response to gliclazide than to metformin and 3.9-fold greater response to gliclazide than patients without HNF-1a mutations [134].

\subsection{Insulin secretagogue agents ----- Non-sulfonylureas}

Meglitinides (repaglinide and nateglinide) represent a new class of insulin secretagogue, structurally unrelated to sulphanylureas by very rapid onset and abbreviated duration of action [135]. Meglitinides stimulate first-phase insulin release in a glucose-sensitive manner and reduce the risk of hypoglycemic events.

\subsubsection{Cytochrome P450 and transporters}

Repaglinide is metabolized by CYP2C8 and CYP3A4 [136]. The CYP2C8*3 variant (Arg139Lys, Lys399Arg) allele was associated with reduced plasma concentrations of repaglinide [137]. Repaglinide mean AUC and maximium plasma concentration $\left(C_{\max }\right)$ were 45 and 39 lower, respectively, in subjects with the CYP2C $8^{*} 1 / * 3$ genotype compared with wild-type homozygotes. Repaglinide AUC was also 13\% lower in subjects with the CYP2C $8^{*} 1{ }^{*} 4$ genotype compared with wild-type homozygotes, although this was not statistically significant [137]. Genetic polymorphisms of CYP3A4, specifically CYP3A4*18, played a major role in contributing to the inter-individual variability in repaglinide's pharmacokinetics [138].

The oral bioavailability of nateglinide is about $73 \%$, and it is rapidly absorbed and extensively metabolized primarily by CYP2C9 in the liver and a smaller fraction by CYP3A4 and CYP2D6 [139]. Nateglinide is confirmed as a substrate of CYP2C9. A previous report showed that the $C Y P 2 C C^{*} 3$ allele was associated with significantly reduced oral nateglinide clearance and pharmacokinetic parameters, which seemed to be unaffected by CYP2C $9^{* 2}$ and CYP2D $6 * 4$ or *5 carriers [140]. 
The meglitinide class drug nateglinide is metabolized by CYP2C9. According to pharmacokinetic data, moderate dose adjustments based on CYP2C9 genotypes may help in reducing interindividual variability in the anti hyperglycemic effects of nateglinide [173]. Carriers of the CYP2C9*3/3 genotype may be at a slightly higher risk of hypoglycemia compared to carriers of $C Y P 2 C 9^{*} 1$, particularly when taking nateglinide doses above $120 \mathrm{mg}$ [140].

Polymorphic organic anion transporting polypeptide 1B1 (SLCO1B1) is a major determinant of repaglinide pharmacokinetics [141]. SLCO1B1 (which codes the OATP1B1 gene, also known as OATP-C, OATP2) polymorphisms are important predictors of repaglinide pharmacokinetics [141]. Repaglinide AUC was $60-110 \%$ greater in participants with the c.521CC genotype than in those with the c.521TT genotype after ingestion of single repaglinide doses ranging from 0.25 to $2 \mathrm{mg}$ [142]. Haplotypes of SLCO1B1*1b/ ${ }^{*} 1 \mathrm{~b}$ (c.388 Gc.521 T) was associated with reduced pharmacokinetic exposure after a single dose oral administration of $2 \mathrm{mg}$ repaglinide, including decreased AUC0- $\infty$ and increased clearance of repaglinide [143].

\subsubsection{Others}

An association of (IGF2BP2) rs1470579 and rs4402960 polymorphisms and development of T2DM and therapeutic efficacy of repaglinide in Chinese T2DM patients was reported. The effects of the repaglinide treatment on FPG $(P<0.05)$ and PPG $(P<0.05)$ were reduced in patients with the rs1470579 AC+CC genotypes compared with AA genotype carriers. Patients with the rs4402960 GT+TT genotypes exhibited an enhanced effect of repaglinide treatment on PINS $(P<0.01)$ compared with GG genotype subjects [144]. SLC30A8 rs13266634 and rs16889462 polymorphisms were associated with repaglinide therapeutic efficacy in Chinese T2DM patients. There were significantly augmented repaglinide effects in patients with rs13266634 CT+TT genotypes on FINS and PINS compared with rs13266634 CC genotype. And patients with rs16889462 GA genotype showed enhanced repaglinide effects on FPG, PPG, and HbAlc compared with GG genotype [31]. Variations in the neural nitric oxide synthase adaptor protein (NOS1AP) involved in insulin secretion and insulin signal pathway may explain some of the variability in response to anti-diabetic drug. A common variant in rs10494366 was associated with repaglinide monotherapy efficacy on insulin resistance in newly diagnosed Shanghai Chinese T2DM patients [145]. And sheng et al study suggested that NAMPT -3186C $>$ T polymorphism was significantly associated with plasma levels of PINS and CHO in Chinese T2DM patients with repaglinide monotherapy [146]. KCNQ1 polymorphism rs2237892 was associated with repaglinide's efficacy on improving insulin sensitivity in Chinese patients with T2DM [15].

\subsection{Biguanides}

Metformin (a biguanide) is among the most widely prescribed drugs and has a glucoregulator effect in the presence of endogenous insulin by reducing gastrointestinal glucose absorption, decreasing endogenous glucose production and reducing peripheral resistance to insulin [147].

\subsubsection{Transporters}

Organic cation transporter 1 (OCT1, gene name SLC22A1) is the major mechanism for metformin entry into hepatocytes and enterocytes [148]. Human OCT1 is highly 
polymorphic. Shu' study provided proof of concept that genetic variation in OCT1 may be associated with variation in response to metformin OCT1 Met420del had reduced activity for metformin [149]. Another study in healthy subjects also confirmed polymorphisms in OCT1 were associated with the renal clearance of metformin [150]. Low-function OCT1 amino acid substitutions Arg61Cys, Ser401Gly, Met420del, and Gly465Arg, and the OCT1 promoter-linked variant rs1867351, were associated with an increase in the renal clearance of metformin by $20 \%$ and $\sim 30 \%$, respectively. These data suggested that a reduction in OCT1 expression or activity may increase renal excretion of metformin [150]. But in T2DM patients, the OCT1 loss-of-function variants, Arg61Cys and Met420del, did not attenuate the $\mathrm{HbA1C}$ reduction achieved by metformin [151].

\subsubsection{Others}

Recently, serine-threonine kinase 11 (STK11), which phosphorylates AMPK, has also been reported to be involved in metformin effects. The STK11 rs8111699 SNP influenced insulin sensitivity and metformin efficacy [152]. Schroner et al showed that the degree of reduction in HbA1c and FPG after ulphonylurea treatment in addition to previous metformin monotherapy was related to TCF7L2 gene polymorphisms [153]. ATM, a gene known to be involved in DNA repair and cell cycle control, played a role in the effect of metformin upstream of AMP-activated protein kinase, and variation in this gene altered glycemic response to metformin [154].

\subsection{Euglycemic agents}

Thiazolidinediones (pioglitazone, rosiglitazone) are insulin sensitizing agents and have glucose and lipid lowering activity. They are selective agonists for the PPAR-Y and decrease insulin resistance and enhance the biological response to endogenously produced insulin.

\subsubsection{Cytochrome P450}

Both rosiglitazone and pioglitazone are extensively metabolized in the liver by CYP2C8 $[155,156]$. Kirchheiner and colleagues considered the influence of the CYP2C $8^{*} 3$ polymorphism on single dose and multiple-dose rosiglitazone $(8 \mathrm{mg})$ pharmacokinetics in German healthy volunteers [157]. Tornio et al evaluated the effects of the CYP2C $8^{*} 3$ allele on single-dose pioglitazone $(15 \mathrm{mg})$ pharmacokinetics in healthy volunteers [158]. The weightadjusted pioglitazone AUC was $34 \%$ lower in CYP2C8 3 homozygotes and $26 \%$ lower in heterozygotes compared with wild-type homozygotes $(P<0.05$, both comparisons). The half-life of pioglitazone was significantly shorter in heterozygotes $(3.4 \mathrm{~h})$ and $C Y P 2 C 8^{*} 3$ homozygotes $(3.3 \mathrm{~h})$ compared with wild-type homozygotes $(4.5 \mathrm{~h})$. Daily et al reported following a single dose of rosiglitazone $4 \mathrm{mg}$, mean AUC was $29 \%$ lower and weightadjusted oral clearance was 39\% higher in heterozygotes compared with wild-type homozygotes [159].

\subsubsection{Others}

Rosiglitazone improves insulin sensitivity by reducing plasma glucose levels and serum insulin, NEFA and triglyceride and by increasing HDL cholesterol levels [160, 161]. Vestergaard et al reported rosiglitazone treatment, in combination with insulin and metformin, of patients with severe primary insulin resistance due to IR mutations and diabetes mellitus, had no impact on the measured estimates of glucose and lipid 
metabolism [162]. It was found that variations SNP45 and SNP276 in the adiponectin gene could affect the rosiglitazone treatment response to the serum adiponectin level and blood glucose control [158]. Sun et al reported that the adiponectin allele 45T/G and -11377C/G polymorphisms were significantly associated with the therapeutic efficacy of multipledose rosiglitazone in Chinese patients with T2DM [163]. And TNF-a G-308A polymorphism might be associated with the therapeutic efficacy of rosiglitazone in T2DM patients [164]. Genetic variations 11482G/A in the perilipin gene could affect weight gain associated with rosiglitazone treatment in patients with T2DM [165]. Brunham et al demonstrated that the ATP-binding cassette transporter subfamily A number 1 (ABCA1) probably had an effect on islet cholesterol homeostasis, and influencing glucose tolerance and insulin secretion [166]. The $219 \mathrm{~K}$ variant of $A B C A 1$ gene was associated with the therapeutic effect of rosiglitazone. The RR homozygotes had a better response to rosiglitazone treatment in terms of insulin sensitivity improvement than minor $\mathrm{K}$ allele carriers [167]. The genetic variations in the PPAR- $\gamma^{2}$ gene could affect the response to rosiglitazone treatment in patients with T2DM. Patients with the Pro12Ala genotype in the PPAR- $\gamma^{2}$ gene had a better therapeutic response to rosiglitazone than did patients with the Pro12Pro genotype [75]. LPIN1 genetic variations rs10192566 could affect rosiglitazone treatment response in T2DM [168]. Zhang et al reptored carriers of A allele of Thr394Thr or Ser allele of Gly482Ser in PGC-1a gene showed a trend for poor therapeutic efficacy to rosiglitazone for A allele of Thr394Thr but a significant improvement in its effectiveness for Gly482Ser. Variants in PGC-1a gene might impair the therapeutic efficacy of rosiglitazone [169].

Himelfarb et al investigated TNF- $\alpha$ and IL-6 expression in leukocytes and their association with polymorphisms and bone markers in diabetic individuals treated with pioglitazone. TNF- $a-308 \mathrm{G}>\mathrm{A}$ polymorphism appeared to be involved in regulation of gene expression independently of hyperglycemia and its interaction with pioglitazone might modify tALP, a important bone marker. IL6 -174G $>C$ variant was related with reduced risk of postprandial hyperglycemia but not with mRNA expression or bone markers [170]. The PPAR- $\gamma$ Pro12Ala gene polymorphism was associated with the response to pioglitazone in Chinese patients with T2DM [171]. Pioglitazone treatment had significantly beneficial effects on serum lipid profile and blood pressure in S447S genotype carriers. The S447X variant in lipoprotein lipase (LPL) gene might be a cause for therapy modification by pioglitazone [172].

\section{Conclusion}

The rapidly increasing prevalence of T2DM is becoming a tremendous public health problem that affects more than 170 million patients worldwide. T2DM is a complex metabolic disorder with two major pathophysiological features: insulin resistance and pancreatic $\beta$-cell dysfunction. The mechanism of this disease remains unknown; however, environmental factors and genetic variations are considered two major contributors to onset and development of T2DM. In this chapter, we introduced gene associated with T2DM, such as: KCNJ11, KCNQ1, SLC30A8, WSF1, CDKAL1, CDKN2A/B, TCF2, TCF7L2, HHEX, JAZF1, PPAR-ү2, IGF2BP2, FTO, THADA, TSPAN8/ LGR5, ADAMTS9, NOTCH2, PTPRD, and SRR. Meanwhile, we described four anti-diabetic drugs pharmacogenetics, including insulin secretagogue agent sulfonylureas (SUs) and meglitinides, biguanides, and euglycemic agents. Genetic polymorphisms in drug-metabolizing enzymes, transporters, receptors, and other drug targets have been linked to interindividual differences in the 
efficacy and toxicity of a number of medications. Mutations in genes important in drug absorption, distribution, metabolism and excretion (ADME) play critical role in pharmacogenetics of diabetes. Numerous genes that influence pharmacogenetics of oral antidiabetics have been described. The investigations of genes associated with T2DM benefits of personalized medicine. And different types of genetic mutations and their influence on the response to therapy with oral antidiabetics are needed future study.

\section{References}

[1] Permutt, M.A., Wasson, J., Cox, N. (2005) Genetic epidemiology of diabetes. J Clin Invest 115, 1431-9.

[2] Clement, J.P.t., Kunjilwar, K., Gonzalez, G., Schwanstecher, M., Panten, U., AguilarBryan, L., Bryan, J. (1997) Association and stoichiometry of K(ATP) channel subunits. Neuron 18, 827-38.

[3] Koster, J.C., Marshall, B.A., Ensor, N., Corbett, J.A., Nichols, C.G. (2000) Targeted overactivity of beta cell K(ATP) channels induces profound neonatal diabetes. Cell 100, 645-54.

[4] Nielsen, E.M., Hansen, L., Carstensen, B., Echwald, S.M., Drivsholm, T., Glumer, C., Thorsteinsson, B., Borch-Johnsen, K., Hansen, T., Pedersen, O. (2003) The E23K variant of Kir6.2 associates with impaired post-OGTT serum insulin response and increased risk of type 2 diabetes. Diabetes 52, 573-7.

[5] Love-Gregory, L., Wasson, J., Lin, J., Skolnick, G., Suarez, B., Permutt, M.A. (2003) E23K single nucleotide polymorphism in the islet ATP-sensitive potassium channel gene (Kir6.2) contributes as much to the risk of Type II diabetes in Caucasians as the PPARgamma Pro12Ala variant. Diabetologia 46, 136-7.

[6] Barroso, I., Luan, J., Middelberg, R.P., Harding, A.H., Franks, P.W., Jakes, R.W., Clayton, D., Schafer, A.J., O'Rahilly, S., Wareham, N.J. (2003) Candidate gene association study in type 2 diabetes indicates a role for genes involved in beta-cell function as well as insulin action. PLOS Biol 1, E20.

[7] Schwanstecher, C., Meyer, U., Schwanstecher, M. (2002) K(IR)6.2 polymorphism predisposes to type 2 diabetes by inducing overactivity of pancreatic beta-cell ATPsensitive $\mathrm{K}(+)$ channels. Diabetes 51, 875-9.

[8] Gloyn, A.L., Weedon, M.N., Owen, K.R., Turner, M.J., Knight, B.A., Hitman, G., Walker, M., Levy, J.C., Sampson, M., Halford, S., McCarthy, M.I., Hattersley, A.T., Frayling, T.M. (2003) Large-scale association studies of variants in genes encoding the pancreatic beta-cell KATP channel subunits Kir6.2 (KCNJ11) and SUR1 (ABCC8) confirm that the KCNJ11 E23K variant is associated with type 2 diabetes. Diabetes $52,568-72$.

[9] Yu, M., Xu, X.J., Yin, J.Y., Wu, J., Chen, X., Gong, Z.C., Ren, H.Y., Huang, Q., Sheng, F.F., Zhou, H.H., Liu, Z.Q. KCNJ11 Lys23Glu and TCF7L2 rs290487(C/T) polymorphisms affect therapeutic efficacy of repaglinide in Chinese patients with type 2 diabetes. Clin Pharmacol Ther 87, 330-5.

[10] Robbins, J. (2001) KCNQ potassium channels: physiology, pathophysiology, and pharmacology. Pharmacol Ther 90, 1-19.

[11] Unoki, H., Takahashi, A., Kawaguchi, T., Hara, K., Horikoshi, M., Andersen, G., Ng, D.P., Holmkvist, J., Borch-Johnsen, K., Jorgensen, T., Sandbaek, A., Lauritzen, T., Hansen, T., Nurbaya, S., Tsunoda, T., Kubo, M., Babazono, T., Hirose, H., Hayashi, 
M., Iwamoto, Y., Kashiwagi, A., Kaku, K., Kawamori, R., Tai, E.S., Pedersen, O., Kamatani, N., Kadowaki, T., Kikkawa, R., Nakamura, Y., Maeda, S. (2008) SNPs in KCNQ1 are associated with susceptibility to type 2 diabetes in East Asian and European populations. Nat Genet 40, 1098-102.

[12] Yasuda, K., Miyake, K., Horikawa, Y., Hara, K., Osawa, H., Furuta, H., Hirota, Y., Mori, H., Jonsson, A., Sato, Y., Yamagata, K., Hinokio, Y., Wang, H.Y., Tanahashi, T., Nakamura, N., Oka, Y., Iwasaki, N., Iwamoto, Y., Yamada, Y., Seino, Y., Maegawa, H., Kashiwagi, A., Takeda, J., Maeda, E., Shin, H.D., Cho, Y.M., Park, K.S., Lee, H.K., Ng, M.C., Ma, R.C., So, W.Y., Chan, J.C., Lyssenko, V., Tuomi, T., Nilsson, P., Groop, L., Kamatani, N., Sekine, A., Nakamura, Y., Yamamoto, K., Yoshida, T., Tokunaga, K., Itakura, M., Makino, H., Nanjo, K., Kadowaki, T., Kasuga, M. (2008) Variants in KCNQ1 are associated with susceptibility to type 2 diabetes mellitus. Nat Genet 40, 1092-7.

[13] Hu, C., Wang, C., Zhang, R., Ma, X., Wang, J., Lu, J., Qin, W., Bao, Y., Xiang, K., Jia, W. (2009) Variations in KCNQ1 are associated with type 2 diabetes and beta cell function in a Chinese population. Diabetologia 52, 1322-5.

[14] Mussig, K., Staiger, H., Machicao, F., Kirchhoff, K., Guthoff, M., Schafer, S.A., Kantartzis, K., Silbernagel, G., Stefan, N., Holst, J.J., Gallwitz, B., Haring, H.U., Fritsche, A. (2009) Association of type 2 diabetes candidate polymorphisms in KCNQ1 with incretin and insulin secretion. Diabetes 58, 1715-20.

[15] Yu, W., Hu, C., Zhang, R., Wang, C., Qin, W., Lu, J., Jiang, F., Tang, S., Bao, Y., Xiang, K., Jia, W. Effects of KCNQ1 polymorphisms on the therapeutic efficacy of oral antidiabetic drugs in Chinese patients with type 2 diabetes. Clin Pharmacol Ther 89, 437-42.

[16] Holmkvist, J., Banasik, K., Andersen, G., Unoki, H., Jensen, T.S., Pisinger, C., BorchJohnsen, K., Sandbaek, A., Lauritzen, T., Brunak, S., Maeda, S., Hansen, T., Pedersen, O. (2009) The type 2 diabetes associated minor allele of rs2237895 KCNQ1 associates with reduced insulin release following an oral glucose load. PLoS One 4, e5872.

[17] Liu, Y., Zhou, D.Z., Zhang, D., Chen, Z., Zhao, T., Zhang, Z., Ning, M., Hu, X., Yang, Y.F., Zhang, Z.F., Yu, L., He, L., Xu, H. (2009) Variants in KCNQ1 are associated with susceptibility to type 2 diabetes in the population of mainland China. Diabetologia 52, 1315-21.

[18] Tan, J.T., Nurbaya, S., Gardner, D., Ye, S., Tai, E.S., Ng, D.P. (2009) Genetic variation in KCNQ1 associates with fasting glucose and beta-cell function: a study of 3,734 subjects comprising three ethnicities living in Singapore. Diabetes 58, 1445-9.

[19] Saxena, R., Voight, B.F., Lyssenko, V., Burtt, N.P., de Bakker, P.I., Chen, H., Roix, J.J., Kathiresan, S., Hirschhorn, J.N., Daly, M.J., Hughes, T.E., Groop, L., Altshuler, D., Almgren, P., Florez, J.C., Meyer, J., Ardlie, K., Bengtsson Bostrom, K., Isomaa, B., Lettre, G., Lindblad, U., Lyon, H.N., Melander, O., Newton-Cheh, C., Nilsson, P., Orho-Melander, M., Rastam, L., Speliotes, E.K., Taskinen, M.R., Tuomi, T., Guiducci, C., Berglund, A., Carlson, J., Gianniny, L., Hackett, R., Hall, L., Holmkvist, J., Laurila, E., Sjogren, M., Sterner, M., Surti, A., Svensson, M., Tewhey, R., Blumenstiel, B., Parkin, M., Defelice, M., Barry, R., Brodeur, W., Camarata, J., Chia, N., Fava, M., Gibbons, J., Handsaker, B., Healy, C., Nguyen, K., Gates, C., Sougnez, C., Gage, D., Nizzari, M., Gabriel, S.B., Chirn, G.W., Ma, Q., Parikh, H., 
Richardson, D., Ricke, D., Purcell, S. (2007) Genome-wide association analysis identifies loci for type 2 diabetes and triglyceride levels. Science 316, 1331-6.

[20] Scott, L.J., Mohlke, K.L., Bonnycastle, L.L., Willer, C.J., Li, Y., Duren, W.L., Erdos, M.R., Stringham, H.M., Chines, P.S., Jackson, A.U., Prokunina-Olsson, L., Ding, C.J., Swift, A.J., Narisu, N., Hu, T., Pruim, R., Xiao, R., Li, X.Y., Conneely, K.N., Riebow, N.L., Sprau, A.G., Tong, M., White, P.P., Hetrick, K.N., Barnhart, M.W., Bark, C.W., Goldstein, J.L., Watkins, L., Xiang, F., Saramies, J., Buchanan, T.A., Watanabe, R.M., Valle, T.T., Kinnunen, L., Abecasis, G.R., Pugh, E.W., Doheny, K.F., Bergman, R.N., Tuomilehto, J., Collins, F.S., Boehnke, M. (2007) A genome-wide association study of type 2 diabetes in Finns detects multiple susceptibility variants. Science 316, 13415.

[21] Scuteri, A., Sanna, S., Chen, W.M., Uda, M., Albai, G., Strait, J., Najjar, S., Nagaraja, R., Orru, M., Usala, G., Dei, M., Lai, S., Maschio, A., Busonero, F., Mulas, A., Ehret, G.B., Fink, A.A., Weder, A.B., Cooper, R.S., Galan, P., Chakravarti, A., Schlessinger, D., Cao, A., Lakatta, E., Abecasis, G.R. (2007) Genome-wide association scan shows genetic variants in the FTO gene are associated with obesity-related traits. PLoS Genet 3, e115.

[22] Steinthorsdottir, V., Thorleifsson, G., Reynisdottir, I., Benediktsson, R., Jonsdottir, T., Walters, G.B., Styrkarsdottir, U., Gretarsdottir, S., Emilsson, V., Ghosh, S., Baker, A., Snorradottir, S., Bjarnason, H., Ng, M.C., Hansen, T., Bagger, Y., Wilensky, R.L., Reilly, M.P., Adeyemo, A., Chen, Y., Zhou, J., Gudnason, V., Chen, G., Huang, H., Lashley, K., Doumatey, A., So, W.Y., Ma, R.C., Andersen, G., Borch-Johnsen, K., Jorgensen, T., van Vliet-Ostaptchouk, J.V., Hofker, M.H., Wijmenga, C., Christiansen, C., Rader, D.J., Rotimi, C., Gurney, M., Chan, J.C., Pedersen, O., Sigurdsson, G., Gulcher, J.R., Thorsteinsdottir, U., Kong, A., Stefansson, K. (2007) A variant in CDKAL1 influences insulin response and risk of type 2 diabetes. Nat Genet 39, 770-5.

[23] Zeggini, E., Scott, L.J., Saxena, R., Voight, B.F., Marchini, J.L., Hu, T., de Bakker, P.I., Abecasis, G.R., Almgren, P., Andersen, G., Ardlie, K., Bostrom, K.B., Bergman, R.N., Bonnycastle, L.L., Borch-Johnsen, K., Burtt, N.P., Chen, H., Chines, P.S., Daly, M.J., Deodhar, P., Ding, C.J., Doney, A.S., Duren, W.L., Elliott, K.S., Erdos, M.R., Frayling, T.M., Freathy, R.M., Gianniny, L., Grallert, H., Grarup, N., Groves, C.J., Guiducci, C., Hansen, T., Herder, C., Hitman, G.A., Hughes, T.E., Isomaa, B., Jackson, A.U., Jorgensen, T., Kong, A., Kubalanza, K., Kuruvilla, F.G., Kuusisto, J., Langenberg, C., Lango, H., Lauritzen, T., Li, Y., Lindgren, C.M., Lyssenko, V., Marvelle, A.F., Meisinger, C., Midthjell, K., Mohlke, K.L., Morken, M.A., Morris, A.D., Narisu, N., Nilsson, P., Owen, K.R., Palmer, C.N., Payne, F., Perry, J.R., Pettersen, E., Platou, C., Prokopenko, I., Qi, L., Qin, L., Rayner, N.W., Rees, M., Roix, J.J., Sandbaek, A., Shields, B., Sjogren, M., Steinthorsdottir, V., Stringham, H.M., Swift, A.J., Thorleifsson, G., Thorsteinsdottir, U., Timpson, N.J., Tuomi, T., Tuomilehto, J., Walker, M., Watanabe, R.M., Weedon, M.N., Willer, C.J., Illig, T., Hveem, K., Hu, F.B., Laakso, M., Stefansson, K., Pedersen, O., Wareham, N.J., Barroso, I., Hattersley, A.T., Collins, F.S., Groop, L., McCarthy, M.I., Boehnke, M., Altshuler, D. (2008) Meta-analysis of genome-wide association data and large-scale replication identifies additional susceptibility loci for type 2 diabetes. Nat Genet 40, 638-45. 
[24] Zeggini, E., Weedon, M.N., Lindgren, C.M., Frayling, T.M., Elliott, K.S., Lango, H., Timpson, N.J., Perry, J.R., Rayner, N.W., Freathy, R.M., Barrett, J.C., Shields, B., Morris, A.P., Ellard, S., Groves, C.J., Harries, L.W., Marchini, J.L., Owen, K.R., Knight, B., Cardon, L.R., Walker, M., Hitman, G.A., Morris, A.D., Doney, A.S., McCarthy, M.I., Hattersley, A.T. (2007) Replication of genome-wide association signals in UK samples reveals risk loci for type 2 diabetes. Science 316, 1336-41.

[25] Sladek, R., Rocheleau, G., Rung, J., Dina, C., Shen, L., Serre, D., Boutin, P., Vincent, D., Belisle, A., Hadjadj, S., Balkau, B., Heude, B., Charpentier, G., Hudson, T.J., Montpetit, A., Pshezhetsky, A.V., Prentki, M., Posner, B.I., Balding, D.J., Meyre, D., Polychronakos, C., Froguel, P. (2007) A genome-wide association study identifies novel risk loci for type 2 diabetes. Nature 445, 881-5.

[26] Chimienti, F., Devergnas, S., Favier, A., Seve, M. (2004) Identification and cloning of a beta-cell-specific zinc transporter, ZnT-8, localized into insulin secretory granules. Diabetes 53, 2330-7.

[27] Kirchhoff, K., Machicao, F., Haupt, A., Schafer, S.A., Tschritter, O., Staiger, H., Stefan, N., Haring, H.U., Fritsche, A. (2008) Polymorphisms in the TCF7L2, CDKAL1 and SLC30A8 genes are associated with impaired proinsulin conversion. Diabetologia 51, 597-601.

[28] Fu, Y., Tian, W., Pratt, E.B., Dirling, L.B., Shyng, S.L., Meshul, C.K., Cohen, D.M. (2009) Down-regulation of ZnT8 expression in INS-1 rat pancreatic beta cells reduces insulin content and glucose-inducible insulin secretion. PLoS One 4, e5679.

[29] Boesgaard, T.W., Zilinskaite, J., Vanttinen, M., Laakso, M., Jansson, P.A., Hammarstedt, A., Smith, U., Stefan, N., Fritsche, A., Haring, H., Hribal, M., Sesti, G., Zobel, D.P., Pedersen, O., Hansen, T. (2008) The common SLC30A8 Arg325Trp variant is associated with reduced first-phase insulin release in 846 non-diabetic offspring of type 2 diabetes patients--the EUGENE2 study. Diabetologia 51, 816-20.

[30] Wu, Y., Li, H., Loos, R.J., Yu, Z., Ye, X., Chen, L., Pan, A., Hu, F.B., Lin, X. (2008) Common variants in CDKAL1, CDKN2A/B, IGF2BP2, SLC30A8, and HHEX/IDE genes are associated with type 2 diabetes and impaired fasting glucose in a Chinese Han population. Diabetes 57, 2834-42.

[31] Huang, Q., Yin, J.Y., Dai, X.P., Wu, J., Chen, X., Deng, C.S., Yu, M., Gong, Z.C., Zhou, H.H., Liu, Z.Q. Association analysis of SLC30A8 rs13266634 and rs16889462 polymorphisms with type 2 diabetes mellitus and repaglinide response in Chinese patients. Eur J Clin Pharmacol 66, 1207-15.

[32] Inoue, H., Tanizawa, Y., Wasson, J., Behn, P., Kalidas, K., Bernal-Mizrachi, E., Mueckler, M., Marshall, H., Donis-Keller, H., Crock, P., Rogers, D., Mikuni, M., Kumashiro, H., Higashi, K., Sobue, G., Oka, Y., Permutt, M.A. (1998) A gene encoding a transmembrane protein is mutated in patients with diabetes mellitus and optic atrophy (Wolfram syndrome). Nat Genet 20, 143-8.

[33] Sandhu, M.S., Weedon, M.N., Fawcett, K.A., Wasson, J., Debenham, S.L., Daly, A., Lango, H., Frayling, T.M., Neumann, R.J., Sherva, R., Blech, I., Pharoah, P.D., Palmer, C.N., Kimber, C., Tavendale, R., Morris, A.D., McCarthy, M.I., Walker, M., Hitman, G., Glaser, B., Permutt, M.A., Hattersley, A.T., Wareham, N.J., Barroso, I. (2007) Common variants in WFS1 confer risk of type 2 diabetes. Nat Genet 39, 951-3.

[34] Sanghera, D.K., Been, L., Ortega, L., Wander, G.S., Mehra, N.K., Aston, C.E., Mulvihill, J.J., Ralhan, S. (2009) Testing the association of novel meta-analysis-derived 
diabetes risk genes with type II diabetes and related metabolic traits in Asian Indian Sikhs. J Hum Genet 54, 162-8.

[35] Lyssenko, V., Jonsson, A., Almgren, P., Pulizzi, N., Isomaa, B., Tuomi, T., Berglund, G., Altshuler, D., Nilsson, P., Groop, L. (2008) Clinical risk factors, DNA variants, and the development of type 2 diabetes. N Engl J Med 359, 2220-32.

[36] Florez, J.C., Jablonski, K.A., McAteer, J., Sandhu, M.S., Wareham, N.J., Barroso, I., Franks, P.W., Altshuler, D., Knowler, W.C. (2008) Testing of diabetes-associated WFS1 polymorphisms in the Diabetes Prevention Program. Diabetologia 51, 451-7.

[37] Sparso, T., Andersen, G., Albrechtsen, A., Jorgensen, T., Borch-Johnsen, K., Sandbaek, A., Lauritzen, T., Wasson, J., Permutt, M.A., Glaser, B., Madsbad, S., Pedersen, O., Hansen, T. (2008) Impact of polymorphisms in WFS1 on prediabetic phenotypes in a population-based sample of middle-aged people with normal and abnormal glucose regulation. Diabetologia 51, 1646-52.

[38] Stancakova, A., Kuulasmaa, T., Paananen, J., Jackson, A.U., Bonnycastle, L.L., Collins, F.S., Boehnke, M., Kuusisto, J., Laakso, M. (2009) Association of 18 confirmed susceptibility loci for type 2 diabetes with indices of insulin release, proinsulin conversion, and insulin sensitivity in 5,327 nondiabetic Finnish men. Diabetes 58, 2129-36.

[39] Schafer, S.A., Mussig, K., Staiger, H., Machicao, F., Stefan, N., Gallwitz, B., Haring, H.U., Fritsche, A. (2009) A common genetic variant in WFS1 determines impaired glucagon-like peptide-1-induced insulin secretion. Diabetologia 52, 1075-82.

[40] Heni, M., Ketterer, C., Thamer, C., Herzberg-Schafer, S.A., Guthoff, M., Stefan, N., Machicao, F., Staiger, H., Fritsche, A., Haring, H.U. Glycemia determines the effect of type 2 diabetes risk genes on insulin secretion. Diabetes 59, 3247-52.

[41] Wei, F.Y., Nagashima, K., Ohshima, T., Saheki, Y., Lu, Y.F., Matsushita, M., Yamada, Y., Mikoshiba, K., Seino, Y., Matsui, H., Tomizawa, K. (2005) Cdk5-dependent regulation of glucose-stimulated insulin secretion. Nat Med 11, 1104-8.

[42] Ubeda, M., Rukstalis, J.M., Habener, J.F. (2006) Inhibition of cyclin-dependent kinase 5 activity protects pancreatic beta cells from glucotoxicity. J Biol Chem 281, 28858-64.

[43] Omori, S., Tanaka, Y., Takahashi, A., Hirose, H., Kashiwagi, A., Kaku, K., Kawamori, R., Nakamura, Y., Maeda, S. (2008) Association of CDKAL1, IGF2BP2, CDKN2A/B, HHEX, SLC30A8, and KCNJ11 with susceptibility to type 2 diabetes in a Japanese population. Diabetes 57, 791-5.

[44] Chidambaram, M., Radha, V., Mohan, V. Replication of recently described type 2 diabetes gene variants in a South Indian population. Metabolism 59, 1760-6.

[45] Xu, M., Bi, Y., Xu, Y., Yu, B., Huang, Y., Gu, L., Wu, Y., Zhu, X., Li, M., Wang, T., Song, A., Hou, J., Li, X., Ning, G. Combined effects of 19 common variations on type 2 diabetes in Chinese: results from two community-based studies. PLoS One 5, e14022.

[46] Moritani, M., Yamasaki, S., Kagami, M., Suzuki, T., Yamaoka, T., Sano, T., Hata, J., Itakura, M. (2005) Hypoplasia of endocrine and exocrine pancreas in homozygous transgenic TGF-beta1. Mol Cell Endocrinol 229, 175-84.

[47] Rane, S.G., Dubus, P., Mettus, R.V., Galbreath, E.J., Boden, G., Reddy, E.P., Barbacid, M. (1999) Loss of Cdk4 expression causes insulin-deficient diabetes and Cdk4 activation results in beta-islet cell hyperplasia. Nat Genet 22, 44-52. 
[48] Tsutsui, T., Hesabi, B., Moons, D.S., Pandolfi, P.P., Hansel, K.S., Koff, A., Kiyokawa, H. (1999) Targeted disruption of CDK4 delays cell cycle entry with enhanced p27(Kip1) activity. Mol Cell Biol 19, 7011-9.

[49] Bieganowski, P., Shilinski, K., Tsichlis, P.N., Brenner, C. (2004) Cdc123 and checkpoint forkhead associated with RING proteins control the cell cycle by controlling eIF2gamma abundance. J Biol Chem 279, 44656-66.

[50] Verploegen, S., Ulfman, L., van Deutekom, H.W., van Aalst, C., Honing, H., Lammers, J.W., Koenderman, L., Coffer, P.J. (2005) Characterization of the role of CaMKI-like kinase (CKLiK) in human granulocyte function. Blood 106, 1076-83.

[51] Grarup, N., Andersen, G., Krarup, N.T., Albrechtsen, A., Schmitz, O., Jorgensen, T., Borch-Johnsen, K., Hansen, T., Pedersen, O. (2008) Association testing of novel type 2 diabetes risk alleles in the JAZF1, CDC123/CAMK1D, TSPAN8, THADA, ADAMTS9, and NOTCH2 loci with insulin release, insulin sensitivity, and obesity in a population-based sample of 4,516 glucose-tolerant middle-aged Danes. Diabetes 57, 2534-40.

[52] Staiger, H., Machicao, F., Kantartzis, K., Schafer, S.A., Kirchhoff, K., Guthoff, M., Silbernagel, G., Stefan, N., Fritsche, A., Haring, H.U. (2008) Novel meta-analysisderived type 2 diabetes risk loci do not determine prediabetic phenotypes. PLoS One 3, e3019.

[53] Gudmundsson, J., Sulem, P., Steinthorsdottir, V., Bergthorsson, J.T., Thorleifsson, G., Manolescu, A., Rafnar, T., Gudbjartsson, D., Agnarsson, B.A., Baker, A., Sigurdsson, A., Benediktsdottir, K.R., Jakobsdottir, M., Blondal, T., Stacey, S.N., Helgason, A., Gunnarsdottir, S., Olafsdottir, A., Kristinsson, K.T., Birgisdottir, B., Ghosh, S., Thorlacius, S., Magnusdottir, D., Stefansdottir, G., Kristjansson, K., Bagger, Y., Wilensky, R.L., Reilly, M.P., Morris, A.D., Kimber, C.H., Adeyemo, A., Chen, Y., Zhou, J., So, W.Y., Tong, P.C., Ng, M.C., Hansen, T., Andersen, G., BorchJohnsen, K., Jorgensen, T., Tres, A., Fuertes, F., Ruiz-Echarri, M., Asin, L., Saez, B., van Boven, E., Klaver, S., Swinkels, D.W., Aben, K.K., Graif, T., Cashy, J., Suarez, B.K., van Vierssen Trip, O., Frigge, M.L., Ober, C., Hofker, M.H., Wijmenga, C., Christiansen, C., Rader, D.J., Palmer, C.N., Rotimi, C., Chan, J.C., Pedersen, O., Sigurdsson, G., Benediktsson, R., Jonsson, E., Einarsson, G.V., Mayordomo, J.I., Catalona, W.J., Kiemeney, L.A., Barkardottir, R.B., Gulcher, J.R., Thorsteinsdottir, U., Kong, A., Stefansson, K. (2007) Two variants on chromosome 17 confer prostate cancer risk, and the one in TCF2 protects against type 2 diabetes. Nat Genet 39, 97783.

[54] Winckler, W., Weedon, M.N., Graham, R.R., McCarroll, S.A., Purcell, S., Almgren, P., Tuomi, T., Gaudet, D., Bostrom, K.B., Walker, M., Hitman, G., Hattersley, A.T., McCarthy, M.I., Ardlie, K.G., Hirschhorn, J.N., Daly, M.J., Frayling, T.M., Groop, L., Altshuler, D. (2007) Evaluation of common variants in the six known maturityonset diabetes of the young (MODY) genes for association with type 2 diabetes. Diabetes 56, 685-93.

[55] Clatworthy, J.P., Subramanian, V. (2001) Stem cells and the regulation of proliferation, differentiation and patterning in the intestinal epithelium: emerging insights from gene expression patterns, transgenic and gene ablation studies. Mech Dev 101, 3-9.

[56] Grant, S.F., Thorleifsson, G., Reynisdottir, I., Benediktsson, R., Manolescu, A., Sainz, J., Helgason, A., Stefansson, H., Emilsson, V., Helgadottir, A., Styrkarsdottir, U., 
Magnusson, K.P., Walters, G.B., Palsdottir, E., Jonsdottir, T., Gudmundsdottir, T., Gylfason, A., Saemundsdottir, J., Wilensky, R.L., Reilly, M.P., Rader, D.J., Bagger, Y., Christiansen, C., Gudnason, V., Sigurdsson, G., Thorsteinsdottir, U., Gulcher, J.R., Kong, A., Stefansson, K. (2006) Variant of transcription factor 7-like 2 (TCF7L2) gene confers risk of type 2 diabetes. Nat Genet 38, 320-3.

[57] Takeuchi, F., Serizawa, M., Yamamoto, K., Fujisawa, T., Nakashima, E., Ohnaka, K., Ikegami, H., Sugiyama, T., Katsuya, T., Miyagishi, M., Nakashima, N., Nawata, H., Nakamura, J., Kono, S., Takayanagi, R., Kato, N. (2009) Confirmation of multiple risk Loci and genetic impacts by a genome-wide association study of type 2 diabetes in the Japanese population. Diabetes 58, 1690-9.

[58] Zeggini, E., McCarthy, M.I. (2007) TCF7L2: the biggest story in diabetes genetics since HLA? Diabetologia 50, 1-4.

[59] Haupt, A., Thamer, C., Heni, M., Ketterer, C., Machann, J., Schick, F., Machicao, F., Stefan, N., Claussen, C.D., Haring, H.U., Fritsche, A., Staiger, H. Gene variants of TCF7L2 influence weight loss and body composition during lifestyle intervention in a population at risk for type 2 diabetes. Diabetes 59, 747-50.

[60] Chang, Y.C., Chiu, Y.F., Ho, L.L., Ting, C.T., Shih, K.C., Curb, J.D., Chen, Y.D., Li, H.Y., Chuang, L.M. TCF7L2 genetic variants and progression to diabetes in the Chinese population: pleiotropic effects on insulin secretion and insulin resistance. J Mol Med 88, 183-92.

[61] Holstein, A., Hahn, M., Korner, A., Stumvoll, M., Kovacs, P. TCF7L2 and therapeutic response to sulfonylureas in patients with type 2 diabetes. BMC Med Genet 12, 30.

[62] Pearson, E.R., Donnelly, L.A., Kimber, C., Whitley, A., Doney, A.S., McCarthy, M.I., Hattersley, A.T., Morris, A.D., Palmer, C.N. (2007) Variation in TCF7L2 influences therapeutic response to sulfonylureas: a GoDARTs study. Diabetes 56, 2178-82.

[63] Bort, R., Martinez-Barbera, J.P., Beddington, R.S., Zaret, K.S. (2004) Hex homeobox gene-dependent tissue positioning is required for organogenesis of the ventral pancreas. Development 131, 797-806.

[64] Horikoshi, M., Hara, K., Ito, C., Shojima, N., Nagai, R., Ueki, K., Froguel, P., Kadowaki, T. (2007) Variations in the HHEX gene are associated with increased risk of type 2 diabetes in the Japanese population. Diabetologia 50, 2461-6.

[65] Schulze, M.B., Al-Hasani, H., Boeing, H., Fisher, E., Doring, F., Joost, H.G. (2007) Variation in the HHEX-IDE gene region predisposes to type 2 diabetes in the prospective, population-based EPIC-Potsdam cohort. Diabetologia 50, 2405-7.

[66] Staiger, H., Stancakova, A., Zilinskaite, J., Vanttinen, M., Hansen, T., Marini, M.A., Hammarstedt, A., Jansson, P.A., Sesti, G., Smith, U., Pedersen, O., Laakso, M., Stefan, N., Fritsche, A., Haring, H.U. (2008) A candidate type 2 diabetes polymorphism near the HHEX locus affects acute glucose-stimulated insulin release in European populations: results from the EUGENE2 study. Diabetes 57, 514-7.

[67] Nakajima, T., Fujino, S., Nakanishi, G., Kim, Y.S., Jetten, A.M. (2004) TIP27: a novel repressor of the nuclear orphan receptor TAK1/TR4. Nucleic Acids Res 32, 4194-204.

[68] Collins, L.L., Lee, Y.F., Heinlein, C.A., Liu, N.C., Chen, Y.T., Shyr, C.R., Meshul, C.K., Uno, H., Platt, K.A., Chang, C. (2004) Growth retardation and abnormal maternal behavior in mice lacking testicular orphan nuclear receptor 4. Proc Natl Acad Sci U S A 101, 15058-63. 
[69] Zhou, D.Z., Liu, Y., Zhang, D., Liu, S.M., Yu, L., Yang, Y.F., Zhao, T., Chen, Z., Kan, M.Y., Zhang, Z.F., Feng, G.Y., Xu, H., He, L. Variations in/nearby genes coding for JAZF1, TSPAN8/LGR5 and HHEX-IDE and risk of type 2 diabetes in Han Chinese. J Hum Genet 55, 810-5.

[70] Auwerx, J. (1999) PPARgamma, the ultimate thrifty gene. Diabetologia 42, 1033-49.

[71] Yen, C.J., Beamer, B.A., Negri, C., Silver, K., Brown, K.A., Yarnall, D.P., Burns, D.K., Roth, J., Shuldiner, A.R. (1997) Molecular scanning of the human peroxisome proliferator activated receptor gamma (hPPAR gamma) gene in diabetic Caucasians: identification of a Pro12Ala PPAR gamma 2 missense mutation. Biochem Biophys Res Commun 241, 270-4.

[72] Buzzetti, R., Petrone, A., Ribaudo, M.C., Alemanno, I., Zavarella, S., Mein, C.A., Maiani, F., Tiberti, C., Baroni, M.G., Vecci, E., Arca, M., Leonetti, F., Di Mario, U. (2004) The common PPAR-gamma2 Pro12Ala variant is associated with greater insulin sensitivity. Eur J Hum Genet 12, 1050-4.

[73] Deeb, S.S., Fajas, L., Nemoto, M., Pihlajamaki, J., Mykkanen, L., Kuusisto, J., Laakso, M., Fujimoto, W., Auwerx, J. (1998) A Pro12Ala substitution in PPARgamma2 associated with decreased receptor activity, lower body mass index and improved insulin sensitivity. Nat Genet 20, 284-7.

[74] de Rooij, S.R., Painter, R.C., Phillips, D.I., Osmond, C., Tanck, M.W., Defesche, J.C., Bossuyt, P.M., Michels, R.P., Bleker, O.P., Roseboom, T.J. (2006) The effects of the Pro12Ala polymorphism of the peroxisome proliferator-activated receptor-gamma2 gene on glucose/insulin metabolism interact with prenatal exposure to famine. Diabetes Care 29, $1052-7$.

[75] Kang, E.S., Park, S.Y., Kim, H.J., Kim, C.S., Ahn, C.W., Cha, B.S., Lim, S.K., Nam, C.M., Lee, H.C. (2005) Effects of Pro12Ala polymorphism of peroxisome proliferatoractivated receptor gamma2 gene on rosiglitazone response in type 2 diabetes. Clin Pharmacol Ther 78, 202-8.

[76] Christiansen, J., Kolte, A.M., Hansen, T.O., Nielsen, F.C. (2009) IGF2 mRNA-binding protein 2: biological function and putative role in type 2 diabetes. J Mol Endocrinol $43,187-95$.

[77] Nielsen, J., Christiansen, J., Lykke-Andersen, J., Johnsen, A.H., Wewer, U.M., Nielsen, F.C. (1999) A family of insulin-like growth factor II mRNA-binding proteins represses translation in late development. Mol Cell Biol 19, 1262-70.

[78] Hinohara, K., Nakajima, T., Sasaoka, T., Sawabe, M., Lee, B.S., Ban, J., Park, J.E., Izumi, T., Kimura, A. (2009) Replication studies for the association of PSMA6 polymorphism with coronary artery disease in East Asian populations. J Hum Genet 54, 248-51.

[79] Ng, M.C., Park, K.S., Oh, B., Tam, C.H., Cho, Y.M., Shin, H.D., Lam, V.K., Ma, R.C., So, W.Y., Cho, Y.S., Kim, H.L., Lee, H.K., Chan, J.C., Cho, N.H. (2008) Implication of genetic variants near TCF7L2, SLC30A8, HHEX, CDKAL1, CDKN2A/B, IGF2BP2, and FTO in type 2 diabetes and obesity in 6,719 Asians. Diabetes 57, 2226-33.

[80] Groenewoud, M.J., Dekker, J.M., Fritsche, A., Reiling, E., Nijpels, G., Heine, R.J., Maassen, J.A., Machicao, F., Schafer, S.A., Haring, H.U., t Hart, L.M., van Haeften, T.W. (2008) Variants of CDKAL1 and IGF2BP2 affect first-phase insulin secretion during hyperglycaemic clamps. Diabetologia 51, 1659-63. 
[81] Ruchat, S.M., Elks, C.E., Loos, R.J., Vohl, M.C., Weisnagel, S.J., Rankinen, T., Bouchard, C., Perusse, L. (2009) Association between insulin secretion, insulin sensitivity and type 2 diabetes susceptibility variants identified in genome-wide association studies. Acta Diabetol 46, 217-26.

[82] Palmer, N.D., Goodarzi, M.O., Langefeld, C.D., Ziegler, J., Norris, J.M., Haffner, S.M., Bryer-Ash, M., Bergman, R.N., Wagenknecht, L.E., Taylor, K.D., Rotter, J.I., Bowden, D.W. (2008) Quantitative trait analysis of type 2 diabetes susceptibility loci identified from whole genome association studies in the Insulin Resistance Atherosclerosis Family Study. Diabetes 57, 1093-100.

[83] van Hoek, M., Langendonk, J.G., de Rooij, S.R., Sijbrands, E.J., Roseboom, T.J. (2009) Genetic variant in the IGF2BP2 gene may interact with fetal malnutrition to affect glucose metabolism. Diabetes 58, 1440-4.

[84] Grarup, N., Rose, C.S., Andersson, E.A., Andersen, G., Nielsen, A.L., Albrechtsen, A., Clausen, J.O., Rasmussen, S.S., Jorgensen, T., Sandbaek, A., Lauritzen, T., Schmitz, O., Hansen, T., Pedersen, O. (2007) Studies of association of variants near the HHEX, CDKN2A/B, and IGF2BP2 genes with type 2 diabetes and impaired insulin release in 10,705 Danish subjects: validation and extension of genome-wide association studies. Diabetes 56, 3105-11.

[85] (2007) Genome-wide association study of 14,000 cases of seven common diseases and 3,000 shared controls. Nature 447, 661-78.

[86] Frayling, T.M., Timpson, N.J., Weedon, M.N., Zeggini, E., Freathy, R.M., Lindgren, C.M., Perry, J.R., Elliott, K.S., Lango, H., Rayner, N.W., Shields, B., Harries, L.W., Barrett, J.C., Ellard, S., Groves, C.J., Knight, B., Patch, A.M., Ness, A.R., Ebrahim, S., Lawlor, D.A., Ring, S.M., Ben-Shlomo, Y., Jarvelin, M.R., Sovio, U., Bennett, A.J., Melzer, D., Ferrucci, L., Loos, R.J., Barroso, I., Wareham, N.J., Karpe, F., Owen, K.R., Cardon, L.R., Walker, M., Hitman, G.A., Palmer, C.N., Doney, A.S., Morris, A.D., Smith, G.D., Hattersley, A.T., McCarthy, M.I. (2007) A common variant in the FTO gene is associated with body mass index and predisposes to childhood and adult obesity. Science 316, 889-94.

[87] Pecioska, S., Zillikens, M.C., Henneman, P., Snijders, P.J., Oostra, B.A., van Duijn, C.M., Aulchenko, Y.S. Association between type 2 diabetes loci and measures of fatness. PLoS One 5, e8541.

[88] Wardle, J., Carnell, S., Haworth, C.M., Farooqi, I.S., O'Rahilly, S., Plomin, R. (2008) Obesity associated genetic variation in FTO is associated with diminished satiety. $J$ Clin Endocrinol Metab 93, 3640-3.

[89] Rippe, V., Drieschner, N., Meiboom, M., Murua Escobar, H., Bonk, U., Belge, G., Bullerdiek, J. (2003) Identification of a gene rearranged by 2 p21 aberrations in thyroid adenomas. Oncogene 22, 6111-4.

[90] Drieschner, N., Belge, G., Rippe, V., Meiboom, M., Loeschke, S., Bullerdiek, J. (2006) Evidence for a 3p25 breakpoint hot spot region in thyroid tumors of follicular origin. Thyroid 16, 1091-6.

[91] Drieschner, N., Kerschling, S., Soller, J.T., Rippe, V., Belge, G., Bullerdiek, J., Nimzyk, R. (2007) A domain of the thyroid adenoma associated gene (THADA) conserved in vertebrates becomes destroyed by chromosomal rearrangements observed in thyroid adenomas. Gene 403, 110-7. 
[92] Simonis-Bik, A.M., Nijpels, G., van Haeften, T.W., Houwing-Duistermaat, J.J., Boomsma, D.I., Reiling, E., van Hove, E.C., Diamant, M., Kramer, M.H., Heine, R.J., Maassen, J.A., Slagboom, P.E., Willemsen, G., Dekker, J.M., Eekhoff, E.M., de Geus, E.J., $t$ Hart, L.M. Gene variants in the novel type 2 diabetes loci CDC123/CAMK1D, THADA, ADAMTS9, BCL11A, and MTNR1B affect different aspects of pancreatic beta-cell function. Diabetes 59, 293-301.

[93] Hu, C., Zhang, R., Wang, C., Wang, J., Ma, X., Lu, J., Qin, W., Hou, X., Bao, Y., Xiang, K., Jia, W. (2009) PPARG, KCNJ11, CDKAL1, CDKN2A-CDKN2B, IDE-KIF11-HHEX, IGF2BP2 and SLC30A8 are associated with type 2 diabetes in a Chinese population. PLoS One 4, e7643.

[94] Gesierich, S., Paret, C., Hildebrand, D., Weitz, J., Zgraggen, K., Schmitz-Winnenthal, F.H., Horejsi, V., Yoshie, O., Herlyn, D., Ashman, L.K., Zoller, M. (2005) Colocalization of the tetraspanins, CO-029 and CD151, with integrins in human pancreatic adenocarcinoma: impact on cell motility. Clin Cancer Res 11, 2840-52.

[95] Kilkenny, D.M., Rocheleau, J.V. (2008) Fibroblast growth factor receptor-1 signaling in pancreatic islet beta-cells is modulated by the extracellular matrix. Mol Endocrinol 22, 196-205.

[96] Somerville, R.P., Longpre, J.M., Jungers, K.A., Engle, J.M., Ross, M., Evanko, S., Wight, T.N., Leduc, R., Apte, S.S. (2003) Characterization of ADAMTS-9 and ADAMTS-20 as a distinct ADAMTS subfamily related to Caenorhabditis elegans GON-1. J Biol Chem 278, 9503-13.

[97] Jungers, K.A., Le Goff, C., Somerville, R.P., Apte, S.S. (2005) Adamts9 is widely expressed during mouse embryo development. Gene Expr Patterns 5, 609-17.

[98] Clark, M.E., Kelner, G.S., Turbeville, L.A., Boyer, A., Arden, K.C., Maki, R.A. (2000) ADAMTS9, a novel member of the ADAM-TS/ metallospondin gene family. Genomics 67, 343-50.

[99] Boesgaard, T.W., Gjesing, A.P., Grarup, N., Rutanen, J., Jansson, P.A., Hribal, M.L., Sesti, G., Fritsche, A., Stefan, N., Staiger, H., Haring, H., Smith, U., Laakso, M., Pedersen, O., Hansen, T. (2009) Variant near ADAMTS9 known to associate with type 2 diabetes is related to insulin resistance in offspring of type 2 diabetes patients--EUGENE2 study. PLoS One 4, e7236.

[100] Lammert, E., Brown, J., Melton, D.A. (2000) Notch gene expression during pancreatic organogenesis. Mech Dev 94, 199-203.

[101] Apelqvist, A., Li, H., Sommer, L., Beatus, P., Anderson, D.J., Honjo, T., Hrabe de Angelis, M., Lendahl, U., Edlund, H. (1999) Notch signalling controls pancreatic cell differentiation. Nature 400, 877-81.

[102] Tsai, F.J., Yang, C.F., Chen, C.C., Chuang, L.M., Lu, C.H., Chang, C.T., Wang, T.Y., Chen, R.H., Shiu, C.F., Liu, Y.M., Chang, C.C., Chen, P., Chen, C.H., Fann, C.S., Chen, Y.T., Wu, J.Y. A genome-wide association study identifies susceptibility variants for type 2 diabetes in Han Chinese. PLoS Genet 6, e1000847.

[103] Chagnon, M.J., Uetani, N., Tremblay, M.L. (2004) Functional significance of the LAR receptor protein tyrosine phosphatase family in development and diseases. Biochem Cell Biol 82, 664-75.

[104] Uetani, N., Kato, K., Ogura, H., Mizuno, K., Kawano, K., Mikoshiba, K., Yakura, H., Asano, M., Iwakura, Y. (2000) Impaired learning with enhanced hippocampal longterm potentiation in PTPdelta-deficient mice. EMBO J 19, 2775-85. 
[105] Ren, J.M., Li, P.M., Zhang, W.R., Sweet, L.J., Cline, G., Shulman, G.I., Livingston, J.N., Goldstein, B.J. (1998) Transgenic mice deficient in the LAR protein-tyrosine phosphatase exhibit profound defects in glucose homeostasis. Diabetes 47, 493-7.

[106] Chagnon, M.J., Elchebly, M., Uetani, N., Dombrowski, L., Cheng, A., Mooney, R.A., Marette, A., Tremblay, M.L. (2006) Altered glucose homeostasis in mice lacking the receptor protein tyrosine phosphatase sigma. Can J Physiol Pharmacol 84, 755-63.

[107] Batt, J., Asa, S., Fladd, C., Rotin, D. (2002) Pituitary, pancreatic and gut neuroendocrine defects in protein tyrosine phosphatase-sigma-deficient mice. Mol Endocrinol 16, 15569.

[108] Zabolotny, J.M., Kim, Y.B., Peroni, O.D., Kim, J.K., Pani, M.A., Boss, O., Klaman, L.D., Kamatkar, S., Shulman, G.I., Kahn, B.B., Neel, B.G. (2001) Overexpression of the LAR (leukocyte antigen-related) protein-tyrosine phosphatase in muscle causes insulin resistance. Proc Natl Acad Sci U S A 98, 5187-92.

[109] Pulido, R., Serra-Pages, C., Tang, M., Streuli, M. (1995) The LAR/PTP delta/PTP sigma subfamily of transmembrane protein-tyrosine-phosphatases: multiple human LAR, PTP delta, and PTP sigma isoforms are expressed in a tissue-specific manner and associate with the LAR-interacting protein LIP.1. Proc Natl Acad Sci U S A 92, 1168690.

[110] Wolosker, H., Blackshaw, S., Snyder, S.H. (1999) Serine racemase: a glial enzyme synthesizing D-serine to regulate glutamate-N-methyl-D-aspartate neurotransmission. Proc Natl Acad Sci U S A 96, 13409-14.

[111] Wolosker, H., Sheth, K.N., Takahashi, M., Mothet, J.P., Brady, R.O., Jr., Ferris, C.D., Snyder, S.H. (1999) Purification of serine racemase: biosynthesis of the neuromodulator D-serine. Proc Natl Acad Sci U S A 96, 721-5.

[112] De Miranda, J., Panizzutti, R., Foltyn, V.N., Wolosker, H. (2002) Cofactors of serine racemase that physiologically stimulate the synthesis of the N-methyl-D-aspartate (NMDA) receptor coagonist D-serine. Proc Natl Acad Sci U S A 99, 14542-7.

[113] Mothet, J.P., Parent, A.T., Wolosker, H., Brady, R.O., Jr., Linden, D.J., Ferris, C.D., Rogawski, M.A., Snyder, S.H. (2000) D-serine is an endogenous ligand for the glycine site of the N-methyl-D-aspartate receptor. Proc Natl Acad Sci U S A 97, 4926-31.

[114] Imai, K., Fukushima, T., Santa, T., Homma, H., Huang, Y., Shirao, M., Miura, K. (1998) Whole body autoradiographic study on the distribution of 14C-D-serine administered intravenously to rats. Amino Acids 15, 351-61.

[115] Inagaki, N., Kuromi, H., Gonoi, T., Okamoto, Y., Ishida, H., Seino, Y., Kaneko, T., Iwanaga, T., Seino, S. (1995) Expression and role of ionotropic glutamate receptors in pancreatic islet cells. FASEB J 9, 686-91.

[116] Gonoi, T., Mizuno, N., Inagaki, N., Kuromi, H., Seino, Y., Miyazaki, J., Seino, S. (1994) Functional neuronal ionotropic glutamate receptors are expressed in the nonneuronal cell line MIN6. J Biol Chem 269, 16989-92.

[117] Bertrand, G., Gross, R., Puech, R., Loubatieres-Mariani, M.M., Bockaert, J. (1993) Glutamate stimulates glucagon secretion via an excitatory amino acid receptor of the AMPA subtype in rat pancreas. Eur J Pharmacol 237, 45-50.

[118] Stancakova, A., Pihlajamaki, J., Kuusisto, J., Stefan, N., Fritsche, A., Haring, H., Andreozzi, F., Succurro, E., Sesti, G., Boesgaard, T.W., Hansen, T., Pedersen, O., Jansson, P.A., Hammarstedt, A., Smith, U., Laakso, M. (2008) Single-nucleotide polymorphism rs7754840 of CDKAL1 is associated with impaired insulin secretion in 
nondiabetic offspring of type 2 diabetic subjects and in a large sample of men with normal glucose tolerance. J Clin Endocrinol Metab 93, 1924-30.

[119] Groop, L.C. (1992) Sulfonylureas in NIDDM. Diabetes Care 15, 737-54.

[120] Niemi, M., Cascorbi, I., Timm, R., Kroemer, H.K., Neuvonen, P.J., Kivisto, K.T. (2002) Glyburide and glimepiride pharmacokinetics in subjects with different CYP2C9 genotypes. Clin Pharmacol Ther 72, 326-32.

[121] Kirchheiner, J., Brockmoller, J., Meineke, I., Bauer, S., Rohde, W., Meisel, C., Roots, I. (2002) Impact of CYP2C9 amino acid polymorphisms on glyburide kinetics and on the insulin and glucose response in healthy volunteers. Clin Pharmacol Ther 71, 28696.

[122] Suzuki, K., Yanagawa, T., Shibasaki, T., Kaniwa, N., Hasegawa, R., Tohkin, M. (2006) Effect of CYP2C9 genetic polymorphisms on the efficacy and pharmacokinetics of glimepiride in subjects with type 2 diabetes. Diabetes Res Clin Pract 72, 148-54.

[123] Zhang, Y., Si, D., Chen, X., Lin, N., Guo, Y., Zhou, H., Zhong, D. (2007) Influence of CYP2C9 and CYP2C19 genetic polymorphisms on pharmacokinetics of gliclazide MR in Chinese subjects. Br J Clin Pharmacol 64, 67-74.

[124] Hart, L.M., Dekker, J.M., van Haeften, T.W., Ruige, J.B., Stehouwer, C.D., Erkelens, D.W., Heine, R.J., Maassen, J.A. (2000) Reduced second phase insulin secretion in carriers of a sulphonylurea receptor gene variant associating with Type II diabetes mellitus. Diabetologia 43, 515-9.

[125] Yokoi, N., Kanamori, M., Horikawa, Y., Takeda, J., Sanke, T., Furuta, H., Nanjo, K., Mori, H., Kasuga, M., Hara, K., Kadowaki, T., Tanizawa, Y., Oka, Y., Iwami, Y., Ohgawara, H., Yamada, Y., Seino, Y., Yano, H., Cox, N.J., Seino, S. (2006) Association studies of variants in the genes involved in pancreatic beta-cell function in type 2 diabetes in Japanese subjects. Diabetes 55, 2379-86.

[126] Rissanen, J., Markkanen, A., Karkkainen, P., Pihlajamaki, J., Kekalainen, P., Mykkanen, L., Kuusisto, J., Karhapaa, P., Niskanen, L., Laakso, M. (2000) Sulfonylurea receptor 1 gene variants are associated with gestational diabetes and type 2 diabetes but not with altered secretion of insulin. Diabetes Care 23, 70-3.

[127] Feng, Y., Mao, G., Ren, X., Xing, H., Tang, G., Li, Q., Li, X., Sun, L., Yang, J., Ma, W., Wang, X., Xu, X. (2008) Ser1369Ala variant in sulfonylurea receptor gene ABCC8 is associated with antidiabetic efficacy of gliclazide in Chinese type 2 diabetic patients. Diabetes Care 31, 1939-44.

[128] Xu, H., Murray, M., McLachlan, A.J. (2009) Influence of genetic polymorphisms on the pharmacokinetics and pharmaco-dynamics of sulfonylurea drugs. Curr Drug Metab 10, 643-58.

[129] Kimber, C.H., Doney, A.S., Pearson, E.R., McCarthy, M.I., Hattersley, A.T., Leese, G.P., Morris, A.D., Palmer, C.N. (2007) TCF7L2 in the Go-DARTS study: evidence for a gene dose effect on both diabetes susceptibility and control of glucose levels. Diabetologia 50, 1186-91.

[130] Winter, W.E., Nakamura, M., House, D.V. (1999) Monogenic diabetes mellitus in youth. The MODY syndromes. Endocrinol Metab Clin North Am 28, 765-85.

[131] Hathout, E.H., Cockburn, B.N., Mace, J.W., Sharkey, J., Chen-Daniel, J., Bell, G.I. (1999) A case of hepatocyte nuclear factor-1 alpha diabetes/MODY3 masquerading as type 1 diabetes in a Mexican-American adolescent and responsive to a low dose of sulfonylurea. Diabetes Care 22, 867-8. 
[132] Pearson, E.R., Liddell, W.G., Shepherd, M., Corrall, R.J., Hattersley, A.T. (2000) Sensitivity to sulphonylureas in patients with hepatocyte nuclear factor-1alpha gene mutations: evidence for pharmacogenetics in diabetes. Diabet Med 17, 543-5.

[133] Sovik, O., Njolstad, P., Folling, I., Sagen, J., Cockburn, B.N., Bell, G.I. (1998) Hyperexcitability to sulphonylurea in MODY3. Diabetologia 41, 607-8.

[134] Pearson, E.R., Starkey, B.J., Powell, R.J., Gribble, F.M., Clark, P.M., Hattersley, A.T. (2003) Genetic cause of hyperglycaemia and response to treatment in diabetes. Lancet $362,1275-81$.

[135] Glamoclija, U., Jevric-Causevic, A. Genetic polymorphisms in diabetes: influence on therapy with oral antidiabetics. Acta Pharm 60, 387-406.

[136] Bidstrup, T.B., Bjornsdottir, I., Sidelmann, U.G., Thomsen, M.S., Hansen, K.T. (2003) CYP2C8 and CYP3A4 are the principal enzymes involved in the human in vitro biotransformation of the insulin secretagogue repaglinide. Br J Clin Pharmacol 56, 30514.

[137] Niemi, M., Leathart, J.B., Neuvonen, M., Backman, J.T., Daly, A.K., Neuvonen, P.J. (2003) Polymorphism in CYP2C8 is associated with reduced plasma concentrations of repaglinide. Clin Pharmacol Ther 74, 380-7.

[138] Ruzilawati, A.B., Gan, S.H. CYP3A4 genetic polymorphism influences repaglinide's pharmacokinetics. Pharmacology 85, 357-64.

[139] McLeod, J.F. (2004) Clinical pharmacokinetics of nateglinide: a rapidly-absorbed, shortacting insulinotropic agent. Clin Pharmacokinet 43, 97-120.

[140] Kirchheiner, J., Meineke, I., Muller, G., Bauer, S., Rohde, W., Meisel, C., Roots, I., Brockmoller, J. (2004) Influence of CYP2C9 and CYP2D6 polymorphisms on the pharmacokinetics of nateglinide in genotyped healthy volunteers. Clin Pharmacokinet 43, 267-78.

[141] Niemi, M., Backman, J.T., Kajosaari, L.I., Leathart, J.B., Neuvonen, M., Daly, A.K., Eichelbaum, M., Kivisto, K.T., Neuvonen, P.J. (2005) Polymorphic organic anion transporting polypeptide $1 \mathrm{~B} 1$ is a major determinant of repaglinide pharmacokinetics. Clin Pharmacol Ther 77, 468-78.

[142] Kalliokoski, A., Neuvonen, M., Neuvonen, P.J., Niemi, M. (2008) The effect of SLCO1B1 polymorphism on repaglinide pharmacokinetics persists over a wide dose range. Br J Clin Pharmacol 66, 818-25.

[143] He, J., Qiu, Z., Li, N., Yu, Y., Lu, Y., Han, D., Li, T., Zhao, D., Sun, W., Fang, F., Zheng, J., Fan, H., Chen, X. Effects of SLCO1B1 polymorphisms on the pharmacokinetics and pharmacodynamics of repaglinide in healthy Chinese volunteers. Eur J Clin Pharmacol 67, 701-7.

[144] Huang, Q., Yin, J.Y., Dai, X.P., Pei, Q., Dong, M., Zhou, Z.G., Huang, X., Yu, M., Zhou, H.H., Liu, Z.Q. IGF2BP2 variations influence repaglinide response and risk of type 2 diabetes in Chinese population. Acta Pharmacol Sin 31, 709-17.

[145] Qin, W., Zhang, R., Hu, C., Wang, C.R., Lu, J.Y., Yu, W.H., Bao, Y.Q., Xiang, K.S., Jia, W.P. A variation in NOS1AP gene is associated with repaglinide efficacy on insulin resistance in type 2 diabetes of Chinese. Acta Pharmacol Sin 31, 450-4.

[146] Sheng, F.F., Dai, X.P., Qu, J., Lei, G.H., Lu, H.B., Wu, J., Xu, X.J., Pei, Q., Dong, M., Liu, Y.Z., Zhou, H.H., Liu, Z.Q. NAMPT -3186C/T polymorphism influences repaglinide response in Chinese patients with type 2 diabetes mellitus. Clin Exp Pharmacol Physiol. 
[147] Kirpichnikov, D., McFarlane, S.I., Sowers, J.R. (2002) Metformin: an update. Ann Intern Med 137, 25-33.

[148] Wang, D.S., Jonker, J.W., Kato, Y., Kusuhara, H., Schinkel, A.H., Sugiyama, Y. (2002) Involvement of organic cation transporter 1 in hepatic and intestinal distribution of metformin. J Pharmacol Exp Ther 302, 510-5.

[149] Shu, Y., Sheardown, S.A., Brown, C., Owen, R.P., Zhang, S., Castro, R.A., Ianculescu, A.G., Yue, L., Lo, J.C., Burchard, E.G., Brett, C.M., Giacomini, K.M. (2007) Effect of genetic variation in the organic cation transporter 1 (OCT1) on metformin action. $J$ Clin Invest 117, 1422-31.

[150] Tzvetkov, M.V., Vormfelde, S.V., Balen, D., Meineke, I., Schmidt, T., Sehrt, D., Sabolic, I., Koepsell, H., Brockmoller, J. (2009) The effects of genetic polymorphisms in the organic cation transporters OCT1, OCT2, and OCT3 on the renal clearance of metformin. Clin Pharmacol Ther 86, 299-306.

[151] Zhou, K., Donnelly, L.A., Kimber, C.H., Donnan, P.T., Doney, A.S., Leese, G., Hattersley, A.T., McCarthy, M.I., Morris, A.D., Palmer, C.N., Pearson, E.R. (2009) Reduced-function SLC22A1 polymorphisms encoding organic cation transporter 1 and glycemic response to metformin: a GoDARTS study. Diabetes 58, 1434-9.

[152] Lopez-Bermejo, A., Diaz, M., Moran, E., de Zegher, F., Ibanez, L. A single nucleotide polymorphism in STK11 influences insulin sensitivity and metformin efficacy in hyperinsulinemic girls with androgen excess. Diabetes Care 33, 1544-8.

[153] Schroner, Z., Javorsky, M., Tkacova, R., Klimcakova, L., Dobrikova, M., Habalova, V., Kozarova, M., Zidzik, J., Rudikova, M., Tkac, I. Effect of sulphonylurea treatment on glycaemic control is related to TCF7L2 genotype in patients with type 2 diabetes. Diabetes Obes Metab 13, 89-91.

[154] Zhou, K., Bellenguez, C., Spencer, C.C., Bennett, A.J., Coleman, R.L., Tavendale, R., Hawley, S.A., Donnelly, L.A., Schofield, C., Groves, C.J., Burch, L., Carr, F., Strange, A., Freeman, C., Blackwell, J.M., Bramon, E., Brown, M.A., Casas, J.P., Corvin, A., Craddock, N., Deloukas, P., Dronov, S., Duncanson, A., Edkins, S., Gray, E., Hunt, S., Jankowski, J., Langford, C., Markus, H.S., Mathew, C.G., Plomin, R., Rautanen, A., Sawcer, S.J., Samani, N.J., Trembath, R., Viswanathan, A.C., Wood, N.W., Harries, L.W., Hattersley, A.T., Doney, A.S., Colhoun, H., Morris, A.D., Sutherland, C., Hardie, D.G., Peltonen, L., McCarthy, M.I., Holman, R.R., Palmer, C.N., Donnelly, P., Pearson, E.R. Common variants near ATM are associated with glycemic response to metformin in type 2 diabetes. Nat Genet 43, 117-20.

[155] Baldwin, S.J., Clarke, S.E., Chenery, R.J. (1999) Characterization of the cytochrome P450 enzymes involved in the in vitro metabolism of rosiglitazone. Br J Clin Pharmacol 48, 424-32.

[156] Jaakkola, T., Laitila, J., Neuvonen, P.J., Backman, J.T. (2006) Pioglitazone is metabolised by CYP2C8 and CYP3A4 in vitro: potential for interactions with CYP2C8 inhibitors. Basic Clin Pharmacol Toxicol 99, 44-51.

[157] Kirchheiner, J., Thomas, S., Bauer, S., Tomalik-Scharte, D., Hering, U., Doroshyenko, O., Jetter, A., Stehle, S., Tsahuridu, M., Meineke, I., Brockmoller, J., Fuhr, U. (2006) Pharmacokinetics and pharmacodynamics of rosiglitazone in relation to CYP2C8 genotype. Clin Pharmacol Ther 80, 657-67. 
[158] Tornio, A., Niemi, M., Neuvonen, P.J., Backman, J.T. (2008) Trimethoprim and the CYP2C $8 * 3$ allele have opposite effects on the pharmacokinetics of pioglitazone. Drug Metab Dispos 36, 73-80.

[159] Daily, E.B., Aquilante, C.L. (2009) Cytochrome P450 2C8 pharmacogenetics: a review of clinical studies. Pharmacogenomics 10, 1489-510.

[160] Saltiel, A.R., Olefsky, J.M. (1996) Thiazolidinediones in the treatment of insulin resistance and type II diabetes. Diabetes 45, 1661-9.

[161] Keen, H. (1994) Insulin resistance and the prevention of diabetes mellitus. N Engl J Med 331, 1226-7.

[162] Vestergaard, H., Lund, S., Pedersen, O. (2001) Rosiglitazone treatment of patients with extreme insulin resistance and diabetes mellitus due to insulin receptor mutations has no effects on glucose and lipid metabolism. J Intern Med 250, 406-14.

[163] Sun, H., Gong, Z.C., Yin, J.Y., Liu, H.L., Liu, Y.Z., Guo, Z.W., Zhou, H.H., Wu, J., Liu, Z.Q. (2008) The association of adiponectin allele $45 T / G$ and $-11377 \mathrm{C} / \mathrm{G}$ polymorphisms with Type 2 diabetes and rosiglitazone response in Chinese patients. Br J Clin Pharmacol 65, 917-26.

[164] Liu, H.L., Lin, Y.G., Wu, J., Sun, H., Gong, Z.C., Hu, P.C., Yin, J.Y., Zhang, W., Wang, D., Zhou, H.H., Liu, Z.Q. (2008) Impact of genetic polymorphisms of leptin and TNFalpha on rosiglitazone response in Chinese patients with type 2 diabetes. Eur J Clin Pharmacol 64, 663-71.

[165] Kang, E.S., Cha, B.S., Kim, H.J., Kim, S.H., Hur, K.Y., Lee, H.J., Shim, W.S., Ahn, C.W., Lee, H.C. (2006) The $11482 \mathrm{G}>\mathrm{A}$ polymorphism in the perilipin gene is associated with weight gain with rosiglitazone treatment in type 2 diabetes. Diabetes Care 29, 1320-4.

[166] Brunham, L.R., Kruit, J.K., Pape, T.D., Timmins, J.M., Reuwer, A.Q., Vasanji, Z., Marsh, B.J., Rodrigues, B., Johnson, J.D., Parks, J.S., Verchere, C.B., Hayden, M.R. (2007) Betacell ABCA1 influences insulin secretion, glucose homeostasis and response to thiazolidinedione treatment. Nat Med 13, 340-7.

[167] Wang, J., Bao, Y.Q., Hu, C., Zhang, R., Wang, C.R., Lu, J.X., Jia, W.P., Xiang, K.S. (2008) Effects of ABCA1 variants on rosiglitazone monotherapy in newly diagnosed type 2 diabetes patients. Acta Pharmacol Sin 29, 252-8.

[168] Kang, E.S., Park, S.E., Han, S.J., Kim, S.H., Nam, C.M., Ahn, C.W., Cha, B.S., Kim, K.S., Lee, H.C. (2008) LPIN1 genetic variation is associated with rosiglitazone response in type 2 diabetic patients. Mol Genet Metab 95, 96-100.

[169] Zhang, K.H., Huang, Q., Dai, X.P., Yin, J.Y., Zhang, W., Zhou, G., Zhou, H.H., Liu, Z.Q. Effects of the peroxisome proliferator activated receptor-gamma coactivator-1alpha (PGC-1alpha) Thr394Thr and Gly482Ser polymorphisms on rosiglitazone response in Chinese patients with type 2 diabetes mellitus. J Clin Pharmacol 50, 1022-30.

[170] Himelfarb, S.T., Silva, F.A., Arazi, S.S., Farjado, C.M., Garofalo, A., Bertolami, M.C., Bertolami, A., Faludi, A., Sampaio, M.F., Rezende, A.A., Hirata, R.D., Hirata, M.H. Tumor necrosis factor-alpha and interleukin-6 expression in leukocytes and their association with polymorphisms and bone markers in diabetic individuals treated with pioglitazone. Drug Metabol Drug Interact 26, 37-40.

[171] Hsieh, M.C., Lin, K.D., Tien, K.J., Tu, S.T., Hsiao, J.Y., Chang, S.J., Lin, S.R., Shing, S.J., Chen, H.C. Common polymorphisms of the peroxisome proliferator-activated receptor-gamma (Pro12Ala) and peroxisome proliferator-activated receptor-gamma 
coactivator-1 (Gly482Ser) and the response to pioglitazone in Chinese patients with type 2 diabetes mellitus. Metabolism 59, 1139-44.

[172] Wang, G., Wang, X., Zhang, Q., Ma, Z. (2007) Response to pioglitazone treatment is associated with the lipoprotein lipase S447X variant in subjects with type 2 diabetes mellitus. Int J Clin Pract 61, 552-7.

[173] Rosenkranz, B., Brockmoller, J. (2005) Effect of genetic polymorphisms in cytochrome p450 (CYP) 2C9 and CYP2C8 on the pharmacokinetics of oral antidiabetic drugs: clinical relevance. Clin Pharmacokinet 44, 1209-25. 


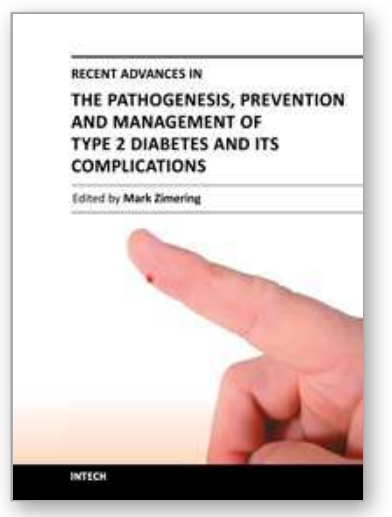

\author{
Recent Advances in the Pathogenesis, Prevention and \\ Management of Type 2 Diabetes and its Complications \\ Edited by Prof. Mark Zimering
}

ISBN 978-953-307-597-6

Hard cover, 442 pages

Publisher InTech

Published online 29, August, 2011

Published in print edition August, 2011

Type 2 diabetes â€œmellitusâ€ affects nearly 120 million persons worldwide- and according to the World Health Organization this number is expected to double by the year 2030. Owing to a rapidly increasing disease prevalence, the medical, social and economic burdens associated with the microvascular and macrovascular complications of type 2 diabetes are likely to increase dramatically in the coming decades. In this volume, leading contributors to the field review the pathogenesis, treatment and management of type 2 diabetes and its complications. They provide invaluable insight and share their discoveries about potentially important new techniques for the diagnosis, treatment and prevention of diabetic complications.

\title{
How to reference
}

In order to correctly reference this scholarly work, feel free to copy and paste the following:

Qiong Huang and Zhao-qian Liu (2011). Pharmacogenetics for T2DM and Anti-Diabetic Drugs, Recent Advances in the Pathogenesis, Prevention and Management of Type 2 Diabetes and its Complications, Prof. Mark Zimering (Ed.), ISBN: 978-953-307-597-6, InTech, Available from:

http://www.intechopen.com/books/recent-advances-in-the-pathogenesis-prevention-and-management-of-type2-diabetes-and-its-complications/pharmacogenetics-for-t2dm-and-anti-diabetic-drugs

\section{INTECH}

open science | open minds

\section{InTech Europe}

University Campus STeP Ri

Slavka Krautzeka 83/A

51000 Rijeka, Croatia

Phone: +385 (51) 770447

Fax: +385 (51) 686166

www.intechopen.com

\section{InTech China}

Unit 405, Office Block, Hotel Equatorial Shanghai

No.65, Yan An Road (West), Shanghai, 200040, China

中国上海市延安西路65号上海国际贵都大饭店办公楼 405 单元

Phone: $+86-21-62489820$

Fax: +86-21-62489821 
(C) 2011 The Author(s). Licensee IntechOpen. This chapter is distributed under the terms of the Creative Commons Attribution-NonCommercialShareAlike-3.0 License, which permits use, distribution and reproduction for non-commercial purposes, provided the original is properly cited and derivative works building on this content are distributed under the same license. 